\title{
Cell-Cycle Kinetics of Neocortical Precursors Are Influenced by Embryonic Thalamic Axons
}

\author{
Colette Dehay, ${ }^{1}$ Pierre Savatier, ${ }^{2}$ Véronique Cortay, ${ }^{1}$ and Henry Kennedy ${ }^{1}$ \\ 1/nstitut National de la Santé et de la Recherche Médicale U371, Cerveau et Vision, 69500 Bron, France, and 2Ecole \\ Normale Supérieure de Lyon Laboratoire de Biologie Moléculaire et Cellulaire, Centre National de la Recherche \\ Scientifique Unité Mixte de Recherche 5665, 69364 Lyon Cedex 07, France
}

Thalamic afferents are known to exert a control over the differentiation of cortical areas at late stages of development. Here, we show that thalamic afferents also influence early stages of corticogenesis at the level of the ventricular zone. Using an in vitro approach, we show that embryonic day 14 mouse thalamic axons release a diffusable factor that promotes the proliferation of cortical precursors over a restricted developmental window. The thalamic mitogenic effect on cortical precursors (1) shortens the total cell-cycle duration via a reduction of the $G_{1}$ phase; (2) facilitates the $G_{1} / S$ transition leading to an increase in proliferative divisions; (3) is significantly reduced by antibodies directed against bFGF; and (4) influences the proliferation of both glial and neuronal precursors and does not preclude the action of signals that induce differentiation in these two lin- eages. We have related these in vitro findings to the in vivo condition: the organotypic culture of cortical explants in which anatomical thalamocortical innervation is preserved shows significantly increased proliferation rates compared with cortical explants devoid of subcortical afferents. These results are in line with a number of studies at subcortical levels showing the control of neurogenesis via afferent fibers in both vertebrates and invertebrates. Specifically, they indicate the mechanisms whereby embryonic thalamic afferents contribute to the known early regionalization of the ventricular zone, which plays a major role in the specification of neocortical areas.

Key words: development; cortex; proliferation; areal specification; mouse; ventricular zone
Cells of the cerebral cortex originate from the ventricular and subventricular zones of the embryonic telencephalon. The heterogeneous population of precursors lining the ventricular zone divide, migrate, and differentiate to form the cerebral cortex. Although many of the developmental events occurring during corticogenesis have been described (Angevine and Sidman, 1961; Smart, 1973; Smart and Smart, 1982; Rakic, 1988; Bayer and Altman, 1991), the contribution of early mechanisms that determine the phenotypes of cortical neurons and specify the identity of cortical areas still has to be resolved (McConnell, 1995).

The sensory periphery exerts an important control over the development of the immature cortical plate via thalamic afferents (O'Leary, 1989). Such afferent specification of cortex (Killackey, 1990 ) is in line with in vivo and in vitro experiments showing that thalamic afferents influence cell survival and differentiation (Repka and Cunningham, 1987; Windrem and Finlay, 1991; Lotto and Price, 1996; Price and Lotto, 1996; Zhou et al., 1999). However, there is also clear evidence that there is a specification of cortical neuron phenotype at the level of the ventricular zone before migration to the cortical plate (Arimatsu et al., 1992; Cohen-Tannoudji et al., 1994; Soriano et al., 1995; Levitt et al., 1997; Miyashita-Lin et al., 1999, Nakagawa et al., 1999).

Given the developmental impact of events in the ventricular

\footnotetext{
Received June 13, 2000; revised Sept. 29, 2000; accepted Oct. 12, 2000.

This work was supported by European Community Biomed and fifth framework programmes, Region Rhône Alpes and Association pour la Recherche sur le Cancer. We are grateful to Ken Knoblauch for implementation of the bootstrap analysis and to P. Giroud for valuable technical help.

Correspondence should be addressed to Colette Dehay, Institut National de la Santé et de la Recherche Médicale U371, Cerveau et Vision, 18 avenue du Doyen Lépine, 69500 Bron, France. E-mail: dehay@lyon151.inserm.fr.

Copyright (C) 2001 Society for Neuroscience 0270-6474/01/210201-14\$15.00/0
}

zone, it is important to know whether they too are influenced by thalamic afferents. Environmental signaling during the final round of mitosis has been shown to be a key event in the specification of the future connectivity of cortical neuroblasts (McConnell and Kaznowski, 1991; Eagleson et al., 1997), and modulation of cell-cycle kinetics contributes to determining areal cytoarchitecture (Dehay et al., 1993; Polleux et al., 1997). There is indirect evidence that, in the primate, thalamic afferents contribute toward specifying the identity of cortical areas during very early stages of cortical development by regulating the rates of neurogenesis in the ventricular zone (Dehay et al., 1993, 1996). Thalamic afferents could influence rates of neuron production either by influencing cell death, which is prevalent in the ventricular zone (Blaschke et al., 1998; Haydar et al., 1999a), or by acting on cell-cycle parameters, in accordance with findings in lower vertebrates and invertebrates (Kollros, 1953, 1982; Williams and Herrup, 1988; Baptista et al., 1990; Selleck and Steller, 1991; Gong and Shipley, 1995).

Here, we show that mouse embryonic thalamic axons release a diffusable factor that promotes proliferation of cortical precursors. This temporally regulated mitogenic effect (1) shortens the total cell-cycle duration of cortical precursors via a reduction of the $G_{1}$ phase, and (2) facilitates the $G_{1} / S$ transition of the cortical precursors, leading to an increase in proliferative divisions. Basic FGF might participate in the cell signaling underlying this mitogenic effect. We have investigated the relevance of these in vitro findings to normal development by showing that proliferation is enhanced in embryonic cortical organotypic slices when thalamocortical connections are conserved. These findings, pointing to the regulation of proliferation by thalamic afferents, indicate how 
these afferents can contribute to the regionalization of the ventricular zone and therefore the specification of neocortical areas.

\section{MATERIALS AND METHODS}

\section{Dissection procedure}

Embryos were removed by cesarean section from timed-pregnant mice (OF1 strain; Iffa Credo, L'Arbresle, France). The plug date was embryonic day 1 (E1). Fetal brains were removed under sterile conditions in iced HBSS containing $10 \mathrm{~mm}$ HEPES. The cerebral hemispheres were detached by medial longitudinal section. The neopallium, including the ventricular zone, the intermediate zone, and the cortical plate, was isolated. Dorsal thalamic nuclei were dissected out.

\section{Culture preparation}

Cortical cells underwent enzymatic dissociation (trypsin $0.2 \% ; 3$ min at $37^{\circ} \mathrm{C}$ ). Trypsin activity was stopped by washing in Glasgow Modified Essential Medium (GMEM; Life Technologies, Gaithersburg, MD) supplemented with $10 \%$ fetal calf serum (FCS). Cells then underwent a mechanical dissociation and were centrifuged for $5 \mathrm{~min}$ at $4^{\circ} \mathrm{C}$ and resuspended in GMEM $+10 \%$ FCS. Viability was estimated by trypan blue exclusion assay, and cells were counted under a hemocytometer. Cells were seeded at a density of $4 \times 10^{5}$ cells per $14 \mathrm{~mm}$ diameter polylysine-laminin-coated glass coverslip and were cultured in $500 \mu \mathrm{l}$ of GMEM $+10 \%$ FCS. The medium was renewed every $4 \mathrm{~d}$. Cell viability was evaluated by means of the trypan blue assay.

Thalamus-conditioned medium (TCM) was prepared from thalamic explants. Explants from E14 or E15 thalamus were obtained from several embryos from the same litter, pooled, and cut into $200 \mu \mathrm{m}$ pieces with a tissue chopper. The explants were cultured in $500 \mu \mathrm{l}$ of GMEM on polylysine-laminin-coated glass coverslips (diameter, $14 \mathrm{~mm}$ ) for $2 \mathrm{~d}$ in vitro (DIV). The amount of explants per coverslip corresponded to that obtained from the dorsal thalamus of one embryo. After $48 \mathrm{hr}$, the culture medium was collected, filtered, and frozen at $-80^{\circ} \mathrm{C}$. In some experiments, we examined the effect of concentrated TCM using Centricon YM-3, 3,000 MW cutoff filters.

When the effect of E18 thalamus was tested, E18 thalamus explants were growth-inactivated by gamma irradiation (137 Cs, 45 Grays) (CIS bio international, Saclay, France) for $30 \mathrm{~min}$ before the culture to prevent any putative effect of proliferating glial cells that could be present in the thalamus at this later stage (Kilpatrick et al., 1993). This treatment did not affect cell viability. We verified that this irradiation protocol, when applied to E14 thalamic explants, did not interfere with the mitogenic effect.

Cortical cultures were grown for $48 \mathrm{hr}$ (2 DIV) in $500 \mu \mathrm{l}$ of GMEM + $10 \%$ FCS or TCM $+10 \%$ FCS before cell-cycle parameters were assayed. The $500 \mu \mathrm{l}$ of TCM were prepared from explants corresponding to the dorsal thalamic nuclei of one embryo (see above). Monoclonal antibody directed against bFGF (F 6162; Sigma, St. Louis, MO) was used at $60 \mathrm{ng} / \mathrm{ml}$.

\section{Western blotting}

Cell lysates from E14 dorsal thalamic nuclei, mouse adult cortex (positive control), and mouse embryonic stem cells (negative control) were prepared as follows. Cells $\left(10^{6}\right)$ were lysed in $100 \mu$ l of lysis buffer $(66 \mathrm{~mm}$ Tris-HCl, pH 6.8, 1.25\% SDS, and 175 mm 2-mercaptoethanol). Samples were analyzed on $7.5 \%$ polyacrylamide gel, followed by immunoblotting on nitrocellulose membranes in $12.5 \mathrm{~mm}$ Tris- $\mathrm{HCl}, 100 \mathrm{~mm}$ glycine, $0.05 \%$ SDS, and $20 \%$ methanol. Membranes were blocked for $2-4 \mathrm{hr}$ in $20 \mathrm{~mm}$ Tris- $\mathrm{HCl}, \mathrm{pH} 7.6,137 \mathrm{~mm} \mathrm{NaCl}, 0.1 \%$ Tween 20 , and $2 \%$ dry milk; washed three times for $10 \mathrm{~min}$ in $20 \mathrm{~mm}$ Tris-HCl, pH 7.6, $137 \mathrm{~mm}$ $\mathrm{NaCl}$, and $0.1 \%$ Tween 20; and incubated for $1 \mathrm{hr}$ with HRP-conjugated secondary antibody 1:5000 (Amersham, Arlington Heights, IL). HRP activity was revealed with the ECL detection kit (Amersham). All incubations with antibodies were performed using Biocomp Navigator (Serlabo, France). The primary antibody was anti-GFAP (Sigma).

\section{Bromodeoxyuridine labeling}

Bromodeoxyuridine (BrdUrd) was added to the medium for either brief [2-3 hr in the case of labeling index (LI) measurements] or prolonged exposures, in the case of cumulative labeling. The cultures were washed with phosphate buffer before being fixed with $70 \%$ alcohol at $-20^{\circ} \mathrm{C}$.

BrdUrd cumulative labeling. BrdUrd cumulative labeling (Nowakowski et al., 1989) was performed in GMEM $+10 \%$ FCS and in TCM $+10 \%$ FCS-grown cultures at 2 DIV, and coverslips were fixed after appropriate exposure times with $70 \%$ ethanol $\left(-20^{\circ} \mathrm{C}\right)$. The culture medium containing $20 \mu \mathrm{g} / \mathrm{ml} \mathrm{BrdUrd} \mathrm{was} \mathrm{renewed} \mathrm{every} 12 \mathrm{hr}$.

Percentage of labeled mitoses. At 2 DIV, cultures grown in GMEM + $10 \%$ FCS and in TCM $+10 \%$ FCS were exposed for $1 \mathrm{hr}$ to BrdUrd, rinsed, and finally fixed after various survival times with ethanol $(70 \%)$ at $-20^{\circ} \mathrm{C}$. For both techniques, a minimum of two coverslips were analyzed for each time point.

For the percentage of labeled mitoses (PLM) experiments (Quastler and Sherman, 1959), statistical significance was tested by means of an F test applied to the ascending slope of the curve. For BrdUrd cumulative labeling, the statistical differences between slopes were tested by means of an $\mathrm{F}$ test, combined with a bootstrap analysis (implemented with Matlab software) that makes it possible to determine whether the intersection of the two slopes is on the $x$-axis.

\section{Immunocytochemistry}

Proliferating cell nuclear antigen/BrdUrd double-labeling. After fixation with $70 \%$ alcohol at $-20^{\circ} \mathrm{C}$, the coverslips were incubated first for $20 \mathrm{~min}$ in TBS $+0.6 \% \mathrm{H}_{2} \mathrm{O}_{2}$, and then for $20 \mathrm{~min}$ in normal goat serum. Proliferating cell nuclear antigen antigen (PCNA) was revealed according to the following three-step immunostaining procedure: mouse antiPCNA (DAKO, PC10, 1:75 in TBS) (Dako, High Wycombe, UK) for 30 min at room temperature (RT), biotinylated goat anti-mouse (1:400 in TBS; Dako) for $30 \mathrm{~min}$ at RT, and peroxidase-conjugated streptavidine (1:500 in TBS; Dako). Peroxidase activity was revealed by incubating the coverslips in DAB $(1 \mathrm{mg} / \mathrm{ml}$ in $0.05 \mathrm{M}$ Tris; Sigma) for $5 \mathrm{~min}$ and then adding $3 \% \mathrm{H}_{2} \mathrm{O}_{2}$ for 10 min. DNA denaturation was subsequently performed by $2 \mathrm{~N} \mathrm{HCl}$ for $30 \mathrm{~min}$, followed by a wash in borate buffer, $\mathrm{pH}$ 8.5. Mouse anti-BrdUrd (1:10; Bioscience) was incubated overnight at $4^{\circ} \mathrm{C}$. Labeling was revealed by a final incubation in FITC rabbit antimouse (1:100; Dako) antibody or Cy3 rabbit anti-mouse (1:400, $1 \mathrm{hr}$ ) (Interchim, Montlucon, France).

Cells in S phase at the time of the pulse were positively stained for BrdUrd. Precursors were identified by means of PCNA labeling. Cell nuclei were counterstained with Hoechst $(1 \mathrm{ng} / \mathrm{ml})$ (Molecular Probes, Eugene, OR). Coverslips were examined using an oil objective microscope $(50 \times$ or $100 \times)$ under UV light to detect FITC (filter $450-490 \mathrm{~nm}$ ) and Hoechst (filter 355-425 nm). PCNA labeling revealed by DAB was observed under white illumination. Coverslips were scanned at regular spacing with a grid corresponding to a field of $0.128 \mathrm{~mm}^{2}$. From 100 to 150 fields were observed per coverslip. A minimum of two coverslips were observed for each condition.

GFAP and MAP2 immunohistochemistry. GFAP and MAP2 were revealed according to the following two-step procedure. Coverslips were rinsed three times in TBS $+0.5 \%$ Triton X-100 and then incubated in a mixture of ethanol (95\%) and acetic acid (5\%) for $20 \mathrm{~min}$. After three rinses in TBS, coverslips were incubated for $20 \mathrm{~min}$ in normal goat serum and rinsed three times before proceeding to primary antibodies incubation as follows. Rabbit anti-GFAP (1:100 in DAKO-diluent) from Sigma (G9269) and mouse anti-MAP2 (1:100 in DAKO-diluent) from Sigma (M4403) were simultaneously incubated overnight at $4^{\circ} \mathrm{C}$. After three TBS rinses to reveal GFAP labeling, goat anti-rabbit-Cy2 (1:200 in DAKO-diluent) (Interchim) was incubated for $1 \mathrm{hr}$ at RT. After three rinses, coverslips were further incubated with goat anti-rabbit-Cy3 (1:200 in DAKO-diluent) (Interchim) for $1 \mathrm{hr}$ at RT to reveal MAP2 labeling. Coverslips were counterstained with Hoechst $(1 \mu \mathrm{g} / \mathrm{ml})$. All experiments were performed at least in duplicate, and a minimum of two coverslips were examined for each condition.

\section{RESULTS}

\section{In vitro assay of cortical precursor proliferation}

A stable in vitro system that permits the accurate quantification of the proliferative activity of cortical precursors was developed. Dissociated neuroblast cultures were prepared from the cerebral wall of the mouse at E14, a stage when thalamic axons are just arriving in the vicinity of the cortex (Bicknese et al., 1994; Cohen-Tannoudji et al., 1994; Polleux et al., 1996).

GMEM supplemented with $10 \%$ FCS was used to grow cortical precursors to optimize proliferation rates (Smith et al., 1988). Under these conditions, cortical precursors show a high rate of proliferation, and rates of cell death are $<5 \%$ (Guibert et al., 1995). This was not the case in Sato medium (Darmon et al., 
1981) in which mouse cortical precursors show a reduced proliferative activity as well as increased levels of cell death.

To characterize the proliferative activity of the culture, we identified the growth fraction (GF), i.e., the proportion of the cycling precursors using immunostaining with an antibody directed against PCNA (Fig. $1 A$ ). PCNA is a $36 \mathrm{kDa}$ nonhistone protein that is involved in DNA replication and functions as a cofactor for DNA polymerase delta (Bravo et al., 1981). Among the different proliferation-associated antigens, PCNA expression is a faithful marker of cycling cells (Bolton et al., 1994). The PCNA expression level is cell-cycle dependent, being upregulated during $G_{1}, S, G_{2}$, and $M$ phases and markedly depressed during $G_{0}$ (Bolton et al., 1994). Flow cytometry analysis shows that in the fixation conditions used in the present study (i.e., ethanol at $-20^{\circ} \mathrm{C}$ ), PCNA expression is optimally detected during all phases of the cell cycle (Sasaki et al., 1993; Teague and el-Naggar, 1994).

In a first instance, we have confirmed that under the experimental conditions used in this study, PCNA expression is restricted to cycling neuroblasts. This is shown in Figure $1 A-C$, which shows that after fixation with ethanol $(70 \%)$ at $-20^{\circ} \mathrm{C}$, PCNA-positive nuclei are restricted to the germinal zones of the brain. In the cortex, the computation of the GF (PCNA-positive cells with respect to the total number of cells in the germinal zones) returns values between 96 and $98 \%$ at E14 and E15. This is in agreement with numerous previous findings in which the GF has been estimated by means of tritiated thymidine or BrdUrd cumulative labeling in vivo. Using ${ }^{3} \mathrm{H}$-thymidine labeling, Reznikov and van der Kooy (1995) report GF values of $99.99 \%$ in E14 and E15 lateral and dorsal rat neocortex. Using BrdUrd cumulative labeling and fluorescence-activated cell sorting analysis, Miller and Nowakowski (1991) report GF values of $90 \%$ in E13 rat. In the mouse, Takahashi et al. $(1993,1995)$ report GF values ranging from 95 to $99 \%$.

Under certain conditions, prolonged BrdUrd exposure (at least equal to the cell-cycle duration) labels all cohorts of precursors going through $\mathrm{S}$ phase and accurately identifies the GF (Fig. 2). The proportion of PCNA-positive cells $(64.8 \%)$ is similar to the proportion of BrdUrd-positive cells (64\%) after prolonged exposure (e.g., $40 \mathrm{hr}$ ), proving that PCNA labeling accurately measures the GF under the experimental conditions used in this study (Fig. 2A). This is further confirmed by the observation that 99.3\% of PCNA-positive cells are also BrdUrd positive after a 40 hr BrdUrd exposure (Fig. 1D,E). The proportion of BrdUrdpositive cells that are PCNA negative (i.e., the cells that have incorporated BrdUrd and subsequently left the cell cycle) was of the order of $2 \%$ after a $40 \mathrm{hr}$ exposure (Fig. $2 \mathrm{~A}$ ), indicating that most precursors are undergoing symmetric proliferative divisions under our experimental conditions. Furthermore, we have specifically addressed whether PCNA expression is downregulated after cell-cycle exit by examining PCNA and MAP2 colocalization (Fig. $1 G-I$ ). Of a total of 7148 MAP2-positive cells, $<0.01 \%$ are PCNA positive (Fig. $2 A$ ). This indicates that PCNA expression is rapidly downregulated in the postmitotic neuron, as has been shown in other cell types (Sasaki et al., 1993), and that therefore, under the present conditions, PCNA immunolabeling accurately identifies the pool of cycling cells.

Cell density (CD) measurements at different time points were used to characterize the proliferative behavior of cortical precursors in the present culture conditions (Fig. 2B). In E14 and E15 cultures, $70-80 \%$ of the cells are PCNA positive at $1 \mathrm{DIV}$. This proportion remains fairly stable for up to 3 DIV and then decreases. Computation of the numbers of newly generated cells (precursors plus postmitotic cells) over time in culture shows that the doubling time of the precursor population is of the order of 30 $\mathrm{hr}$, indicating a mean cell-cycle duration of $30 \mathrm{hr}$ in the first $2 \mathrm{~d}$. This duration is in agreement with the recently reported values of $25 \mathrm{hr}$ in E15 mouse cortical slices (Haydar et al., 1999b). In the present in vitro conditions, there is a lengthening of the mean cell-cycle duration to a value of $43 \mathrm{hr}$ at $4 \mathrm{DIV}$. In vivo, the mean cell-cycle duration is considerably shorter (15 hr) but shows a comparable $30 \%$ increase over the same period (Takahashi et al., 1995).

The analysis of the variation of the relative proportions of PCNA-positive cells and postmitotic cells within the population of newly generated cells with time indicates changes in the mode of division (Fig. 2C). During the first $24 \mathrm{hr}$, precursors produce 10 times more precursors than postmitotic cells, indicating that proliferative divisions are prevalent at this stage. From DIV 3 to 4 , precursors produce only six times more precursors than postmitotic cells, showing that there is a significant decrease in the prevalence of proliferative divisions and an increase in the incidence of differentiative divisions generating postmitotic cells. Again, the decrease in the incidence of proliferative divisions in vitro mirrors a similar decrease reported in vivo (Takahashi et al., 1995).

Serial examination of the cultures over several days revealed the appearance of morphologically differentiated neurons and glia (Fig. 1I). Few cells were found to be GFAP positive in the E14 or E15 cultures at 1 DIV [in agreement with the observation of Temple and Davis (1994)], and this number increased substantially over time (Fig. 3D). The number of MAP2-positive (Fig. $3 C$ ) cells is substantially higher than the number of GFAPpositive cells, confirming that most precursors differentiate into postmitotic neurons. These results indicate that the signals that regulate proliferation and differentiation of cortical precursors into the neuronal and glial lineages continue to operate in the culture conditions implemented in this study, with a temporal schedule reminiscent of that observed during corticogenesis in vivo.

\section{Thalamic axons influence the proliferative behavior of cortical precursors}

E14 thalamic explants were first grown in GMEM on polylysinelaminin-coated slides. After 2-4 DIV, most of the explants exhibited substantial outgrowth of putative axons extending several hundred micrometers. Control experiments showed that thalamic cells do not migrate out of the explants along the axons. Cortical precursors were then plated in GMEM $+10 \%$ FCS onto the coverslips with the thalamic explant. The medium was renewed every $12 \mathrm{hr}$, thereby preventing the buildup of mitogenic factors in the bulk of the medium and making it possible to detect localized effects. After 2-3 DIV, there was a significant increase in cell density in the immediate vicinity of axon terminals (Fig. 4A-D). Because this could result from an increase in the frequency of proliferative divisions or survival, or both, we assessed GF in the vicinity of axonal terminals compared with locations at $>60 \mu \mathrm{m}$ from the terminals (Fig. $4 E, F$ ). This shows that embryonic thalamic neurons release via their axons a mitogenic factor, which leads to an increase in the proportion of daughter cells that remain in the cell cycle.

\section{Influence of TCM on cell-cycle kinetics}

To characterize mitogenic effects, we developed an assay based on the use of TCM. It was necessary to ensure that the thalamic 


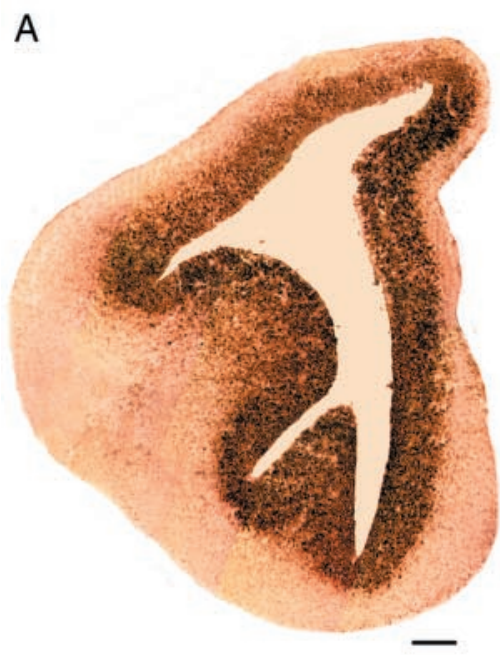

D

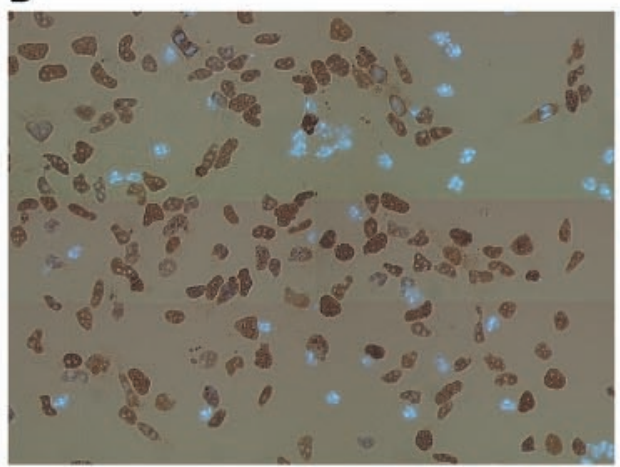

A, PCNA expression in the telencephalic wall of an E14 hemisphere mouse that has been fixed with ethanol $(70 \%)$ at $-20^{\circ} \mathrm{C}$. PCNA-immunopositive nuclei have been revealed by DAB staining and appear dark brown. This shows that PCNA-positive neuroblasts are restricted to the proliferative zone. Scale bar, $100 \mu \mathrm{m}$. $B$, A high-power microphotograph of E14 dorsal cortex showing the distribution of cells in $\mathrm{S}$ phase (after a BrdUrd injection and 2 hr survival time). BrdUrd-positive cells are immunostained with $\mathrm{Cy} 3$ and appear red when viewed under fluorescent illumination. The majority of labeled cells are located in the top part of the ventricular zone. $C$, Corresponds to the same section as in $B$. PCNA-immunopositive cells are revealed by DAB staining, and the section has been counterstained with bisbenzimide. This shows that PCNA-immunopositive cells are restricted to the germinal zones. Scale bar, $50 \mu \mathrm{m}$. $D$, PCNA-positive precursors visualized by DAB immunochemistry (brown nuclei) after 2 DIV. Postmitotic cells are stained by bisbenzimide (blue fluorescence) $E$, BrdUrd-positive nuclei (red fluorescence) after a prolonged BrdUrd exposure (same field as $D$ ). Scale bar, $100 \mu \mathrm{m}$. $F-H$, Double immunostaining for MAP2 and PCNA showing the absence of colocalization of these two markers. $F$, PCNA+ precursors are immunostained with DAB (brown); nuclei of postmitotic cells are stained with bisbenzimide. $G$, Same field as $F$, showing MAP2 immunostaining (red fluorescence). Scale bar, $50 \mu \mathrm{m}$. H, High-power magnification of PCNA + precursors (brown) and MAP2 immunolabeling. Note that MAP2positive cells are PCNA negative. Scale bar, $20 \mu \mathrm{m}$. I, Immunostaining with MAP2 ( $f l u$ orescent red), PCNA (brown), and GFAP (green). E15 cultures, 3 DIV. All GFAPpositive cells are PCNA positive. Scale bar, $100 \mu \mathrm{m}$.
$\mathrm{F}$

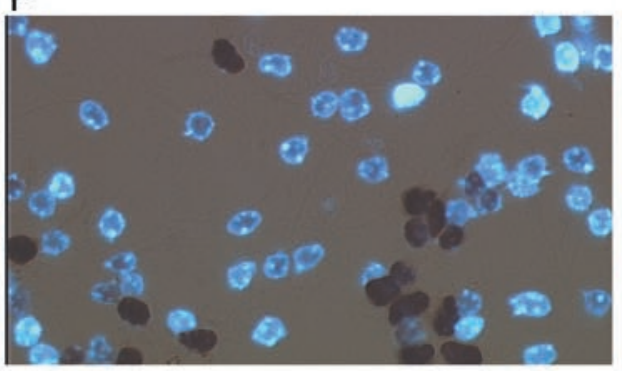

$\mathrm{H}$

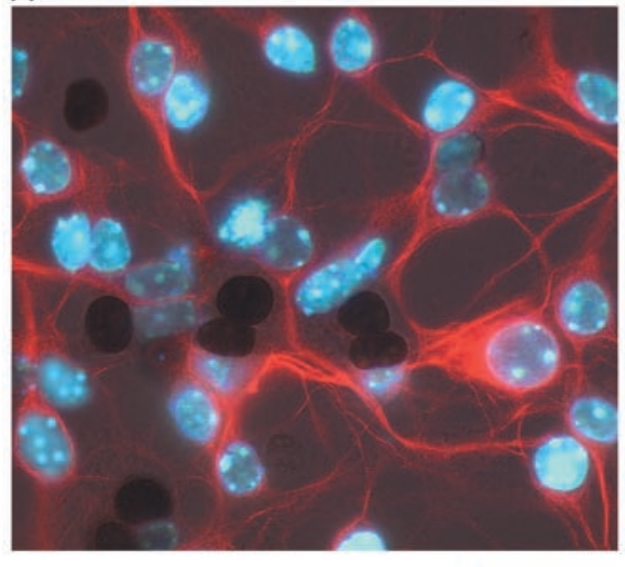

B

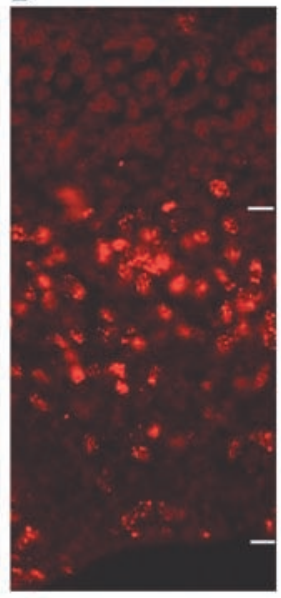

C

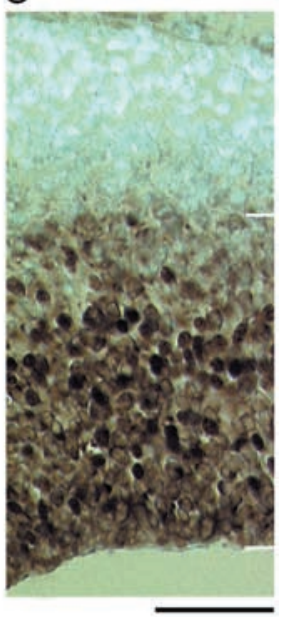

\section{E}

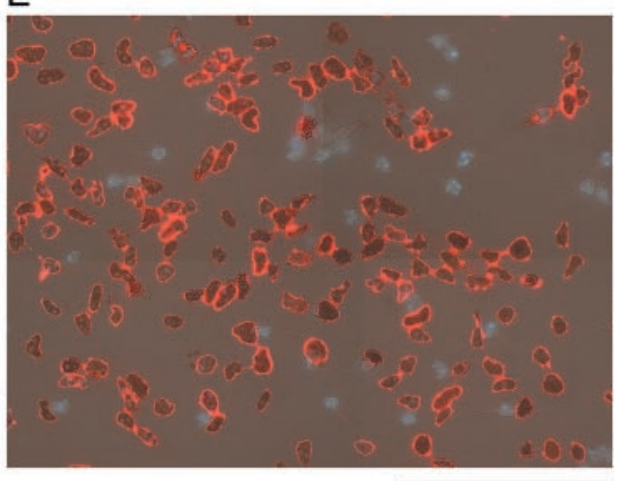

G
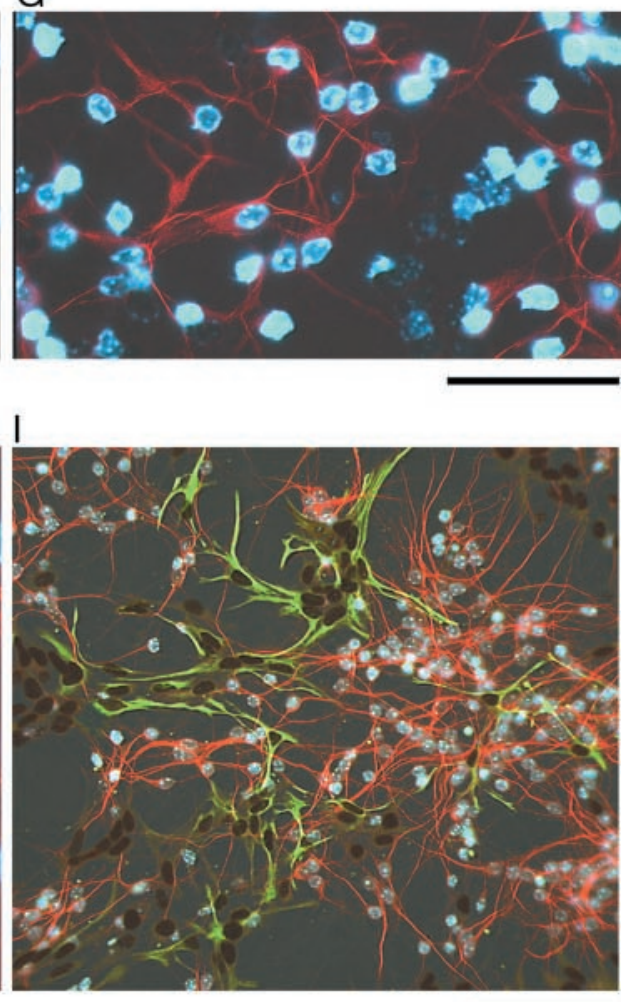

cultures used for generating TCM were free of glia because glial cells release a number of factors that exert mitogenic, differenti- ation, and survival effects (Kilpatrick et al., 1993) that in vivo would not be in a position to influence the developing cortex. 
E14 cortex
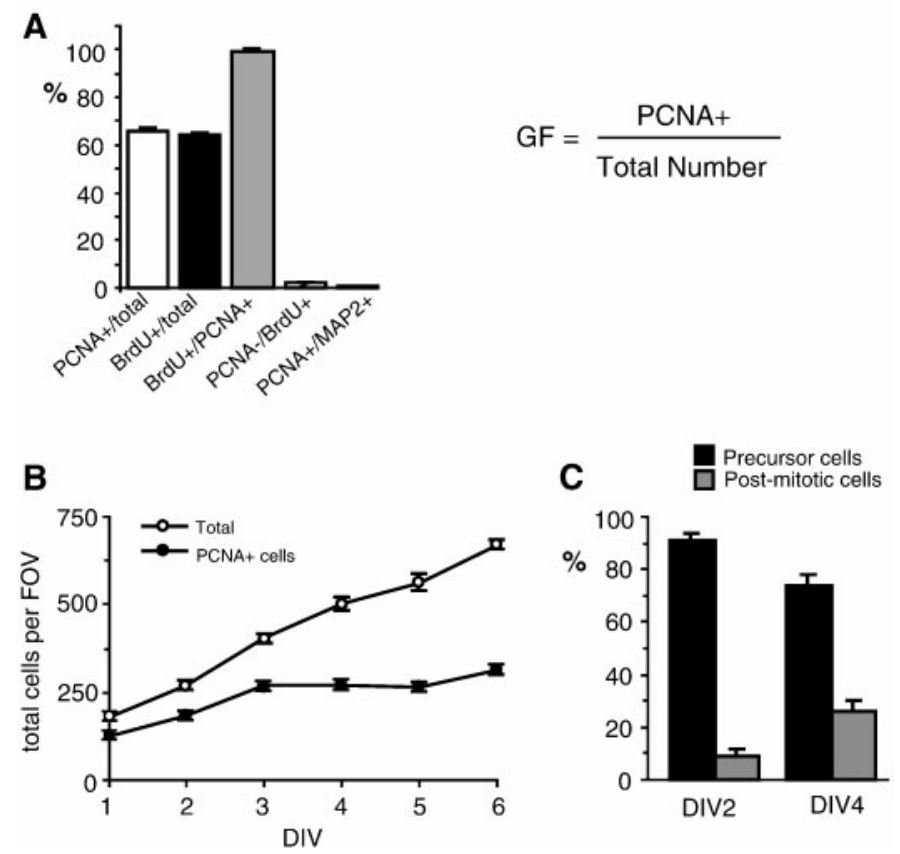

Figure 2. Characterization of cell cultures and quantification of the GF. $A$, Percentage of cycling cells, identified by PCNA immunostaining, corresponds to the GF. In a cell population undergoing proliferative divisions, prolonged $(40 \mathrm{hr})$ BrdUrd exposure (at least equal to the cell-cycle duration) labels all cohorts of precursors going through $\mathrm{S}$ phase and identifies the GF. The GF values returned by the cumulative BrdUrd method $(64 \%)$ are nearly identical to those returned by the percentage of PCNA+ cells $(64.8 \%)$ in the same population. The ratio PCNA-/Br$\mathrm{dUrd}+$ measures the fraction of BrdUrd + cells that quit the cell cycle. The percentage of MAP2+ cells that also express PCNA approaches zero, indicating that PCNA expression is downregulated in postmitotic neurons. $B, C$, Characterization of E14 cortical cultures growing in GMEM $+10 \%$ FCS . B, Increase per field of view (FOV) in total cell number and in PCNA+ cells. The total population doubles during the first $48 \mathrm{hr}$. $C$, Proportions of precursor and postmitotic cells in the population of newly generated cells.

TCM was prepared by growing E14 thalamic explants for 2 DIV in GMEM without serum. At E14, neurogenesis is terminated in the dorsal thalamus, and the use of GMEM ensures that no cell proliferation is induced, as confirmed by the absence of ${ }^{3} \mathrm{H}$ thymidine incorporation (data not shown). Under these culture conditions, there are numerous axonal processes growing out of the thalamic explants, and no cells are labeled by GFAP. The absence of glial cells in the E14 thalamic explants was confirmed by GFAP immunoblotting (Fig. $4 G$ ).

The influence of TCM on cortical precursors was tested over the first 2 DIV. TCM was not found to influence the viability of cortical cultures (data not shown). In all experiments, TCM leads to a significant increase in cell density in the cortical cultures. To test whether the mitogenic effect of TCM was dose dependent, we have examined the influence of different dilutions of TCM on cell density in cortical cultures (see Fig. $6 A$ ). The results show that the mitogenic effect is decreased twofold with a $30 \%$ dilution of TCM. It is almost completely abolished when dilution is superior to $50 \%$. This indicates that, within the range of dilutions tested, the mitogenic effect of TCM is proportional to the concentration of the active factor(s). It also indicates that the concentration of active factor(s) in undiluted TCM is close to the threshold under

\section{E15 cortex}

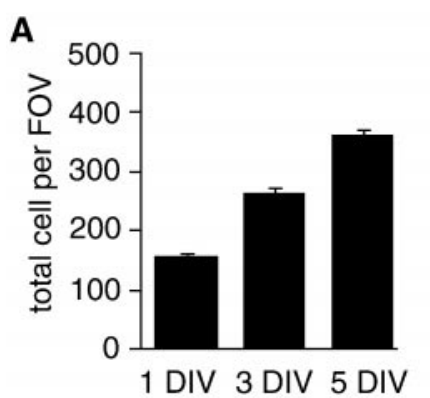

C

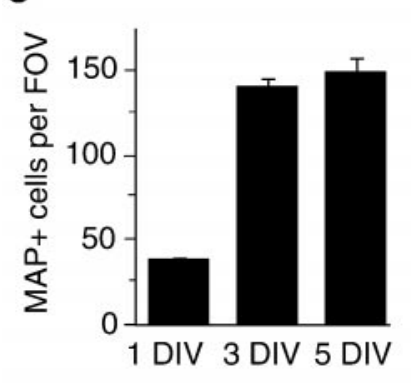

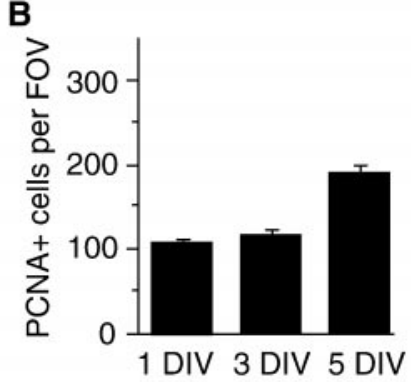

D

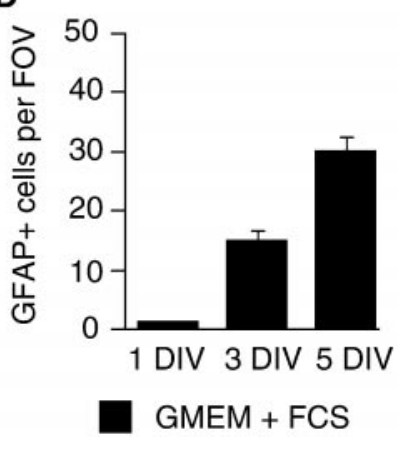

Figure 3. Variations of different cell types per field of view (FOV) over time in an E15 culture. $A$, Variations in total number of cells; $B$, variations in PCNA+ cells; $C$, variations in MAP2 + cells; and $D$, variations in GFAP + cells.

which the mitogenic effect starts to be detected. Hence, it is likely that the concentration of TCM would lead to stronger mitogenic effects.

We have further characterized the mitogenic effect of TCM by determining its influence on (1) GF, and (2) LI of the population of cycling cells (i.e., the percentage of PCNA-positive cells that have incorporated BrdUrd after a pulse exposure) (Fig. 5). The $\mathrm{LI}$ indicates the proportions of precursors in $\mathrm{S}$ phase at the time of the BrdUrd pulse and therefore reflects the relative duration of the $S$ phase (Ts) with respect to the total duration of the cell cycle. Because Ts is largely invariant, variations of LI reflect changes in the duration of the cell cycle (Tc) (Waechter and Jaensch, 1972; Schultze et al., 1974; Schmahl, 1983; Reznikov and van der Kooy, 1995) (Fig. 5).

We examined the effects of TCM on cultures in which high levels of proliferation and minimal levels of cell death lead to a doubling of cell density during the first $48 \mathrm{hr}$ and sustained growth for 5 DIV (see above). Under these conditions, TCM caused a $17-36 \%$ increase in cell density, an 11-17\% increase in $\mathrm{GF}$, and a $12-28 \%$ increase in LI (Fig. $6 B-E$, Table 1). The magnitude of the increase in CD, GF, and LI was significantly augmented when TCM was concentrated 10 or 20 times with Centricon filters (Fig. 6, compare $H, I$, and $J$ to $E$ ).

One possibility is that the mitogenic factor released by thalamic axons acts by increasing the responsiveness of precursor cells to exogenous mitogens provided by FCS present in the culture media. To test this hypothesis, we examined whether TCM can increase proliferation in the absence of FCS (Fig. 6F). This showed that TCM alone leads to a $42-60 \%$ increase in density, an $11-26 \%$ increase in GF, and a $24-26 \%$ increase in LI (Table 1).

The proliferative behavior of the cultures supplemented with 


\section{E14 cortex in presence of E14 thalamic explants}
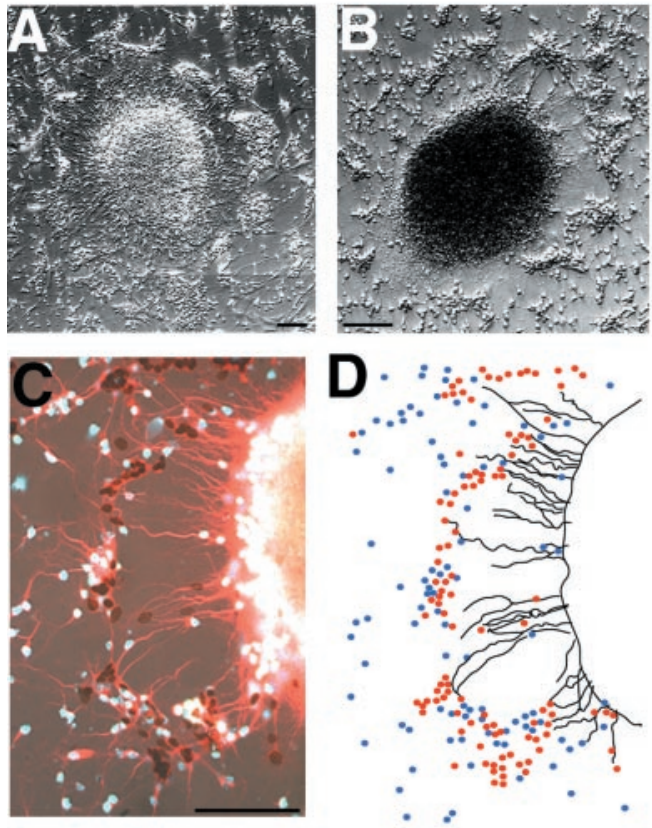

- PCNA - Hoechst
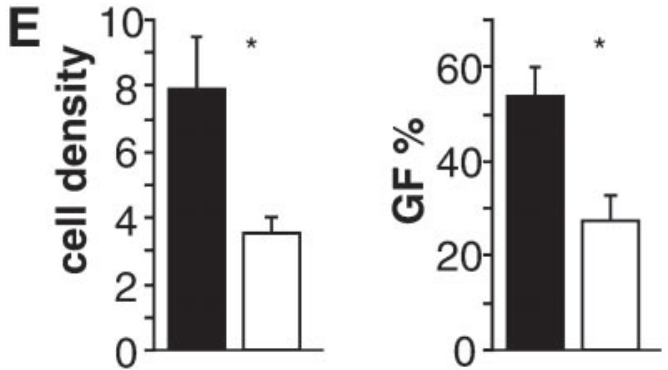

$\mathbf{F}$
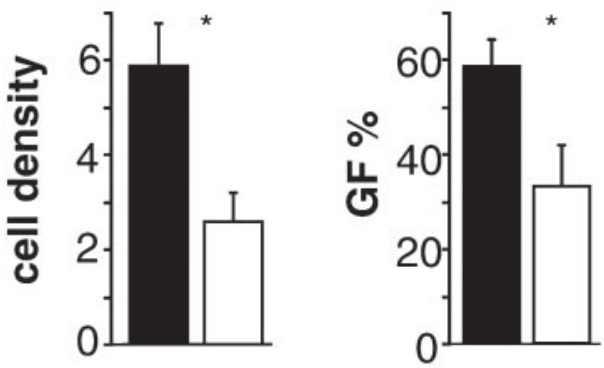

$<60 \mu \mathrm{m}$ from axon terminal $>60 \mu \mathrm{m}$ from axon terminal precursors growing in the region of thalamic putative axons revealed by immunocytochemical identification of MAP2 (red) and PCNA (brown). $D$, Drawing of the explant shown in $C$. PCNA+ cells (red dots) and differentiated cells (blue dots). E, $F$, Cell density and proportion of undifferentiated cycling precursors in the vicinity of thalamic axon terminals (2 experiments). $G$, Western blot for GFAP detection in E14 dorsal thalamus, adult mouse cortex (positive control), and embryonic stem $(E S)$ cells (negative control). The $50 \mathrm{kDa}$ protein was detected with anti-GFAP antibody in the adult cortex but not in the embryonic thalamus. Statistical significance of the results: Mann-Whitney $U$ test; $* p<0.05$. Scale bars, $100 \mu \mathrm{m}$.

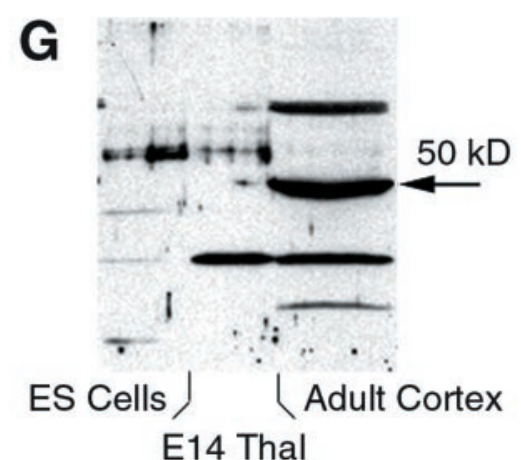

TCM and no FCS (Fig. $6 F$ ) compared with cultures with FCS alone (Fig. 6G) shows that the magnitude of the mitogenic effect of TCM is similar to that of FCS, which is known to contain a number of growth-promoting factors.

The specificity of the mitogenic effect was investigated by determining its developmental time window (Fig. 7). This shows that the mitogenic effect of TCM is restricted to a narrow time period because E18 cortical precursors are no longer competent to respond to the thalamic mitogenic effect (Fig. 7A-C). At later developmental stages, thalamic neurons cease to influence neurogenesis because TCM obtained from E18 thalamus is unable to promote proliferation of E15 cortical precursors (Fig. $7 D-F$ ). This absence of a mitogenic effect of E18 thalamus is found with and without FCS (data not shown). The loss of response of E18 precursors to TCM is relatively selective because the mitogenic effect of FCS is conserved at this age (Fig. 7G-I). Altogether, these results indicate that the responsiveness of cortical cells to the thalamus-derived factor is selectively modulated during development.

We characterized the influence of TCM by estimating the duration of individual phases of the cell cycle by means of BrdUrd cumulative labeling (Nowakowski et al., 1989; Alexiades and Cepko, 1996) and the PLM technique (Quastler and Sherman, 1959). Here, we have improved the BrdUrd cumulative labeling method as a tool to measure the length of the cell cycle by computing the LI values within the population of cycling cells. In such a system, prolonged exposure to BrdUrd at least equal to Tc - Ts generates LI values of $100 \%$. This cannot be the case when LI is computed with respect to the total population (cycling and quiescent cells). This makes it possible to accurately determine the Tc value by projecting the extrapolated $100 \%$ LI value on the $x$-axis.

BrdUrd cumulative labeling has been performed in E14 precursors. The results show significantly different slopes for control 
A

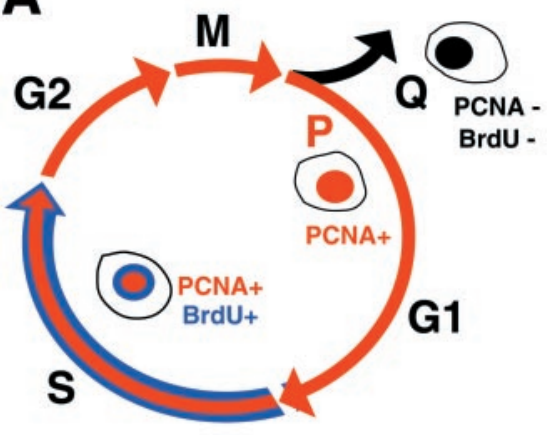

$$
\mathrm{GF}=\frac{\mathrm{PCNA}+}{\text { Total Number }}=\frac{\mathrm{P}}{\mathrm{P}+\mathrm{Q}} \times 100
$$

A
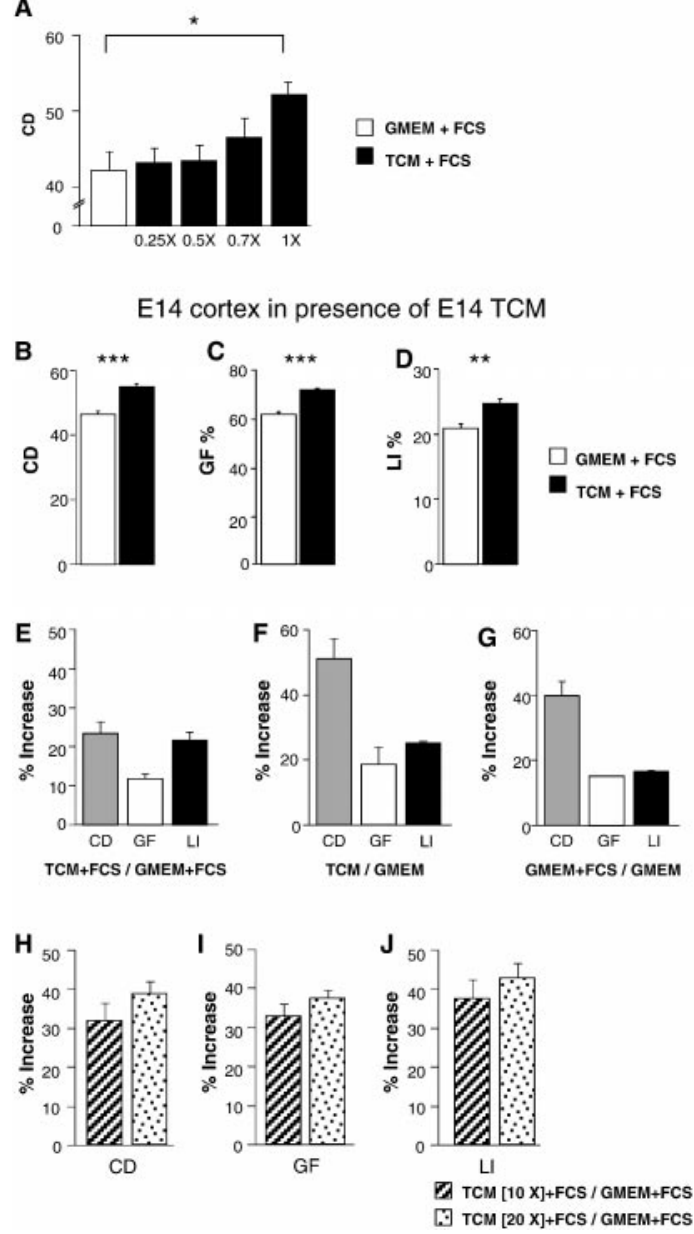

Figure 6. A, Dose-response effect of E14 TCM on cell density of E14 cortical precursors. $B-D$, Effect of TCM on cell density $(C D)$, growth fraction $(G F)$, and labeling index $(L I)$, respectively, in E14 cultures. $E-G$, Mean percentage increase of $\mathrm{CD}, \mathrm{GF}$, and $\mathrm{LI}$ in cortical precursors grown in TCM (Table 1). E, TCM $+10 \%$ FCS compared with cortical precursors grown in GMEM $+10 \%$ FCS (values from 6 experiments). $F$, TCM alone, two experiments. $G$, FCS alone, two experiments. $H-J$, Mean percentage increase of $\mathrm{CD}$, GF, and $\mathrm{LI}$ in cortical precursors grown in $10 \times$ and $20 \times$ concentrated TCM.

and TCM-treated precursors, indicating different cell-cycle times (Fig. 8A). Extrapolation to the $100 \%$ LI value shows that Tc is reduced in TCM cultures compared with controls, whereas the length of Ts (derived from the extrapolation of LI $=0$ on the negative limb of the $x$-axis) is identical under both conditions (Fig. 8A). The data return a duration of $\mathrm{S}$ phase of the order of $3 \mathrm{hr}$, which is close to the $4 \mathrm{hr}$ Ts value reported in vivo (Takahashi et al., 1995). Measurements of the length of the $G_{2} / M$ phases by means of the PLM technique return identical values of $3.5 \mathrm{hr}$ under both culture conditions (Fig. 8B). Subtraction of Ts $+\mathrm{TG}_{2} / \mathrm{M}$ values from Tc returns a $\mathrm{G}_{1}$ duration $\left(\mathrm{TG}_{1}\right)$ of $19 \mathrm{hr}$ in the case of TCM-treated cultures, which indicates a reduction of $30 \%$, compared with the $\mathrm{TG}_{1}$ of control cultures $(25 \mathrm{hr})$. Together, these results show that the thalamus-derived factor modulates Tc of cortical precursors by selectively shortening the $G_{1}$ duration.

\section{Inhibition of TCM mitogenic effect by anti-bFGF}

We have sought to investigate the identity of the thalamusderived extracellular signal. A candidate molecule is bFGF, which is a particularly effective mitogen for cortical precursors (Ghosh and Greenberg, 1995; Cavanagh et al., 1997; Vaccarino et al., 1999) and is present in vivo in the E15 thalamus neurons (Lotto et al., 1997) and axons as shown in Figure $9 A$. We first characterized the influence of bFGF (10-50 $\mathrm{ng} / \mathrm{ml})$ on E14 precursors. bFGF was found to stimulate proliferation by significantly increasing the cell density, GF, and LI values (data not shown). We explored the potential role of bFGF by the addition of a neutralizing monoclonal antibody against bFGF (which recognizes bFGF but not acidic FGF) to cortical precursors cultured in TCM and to precursors grown in the vicinity of thalamic axons. In both cases, although this treatment did not totally abolish the mitogenic effect of TCM, it significantly decreased proliferation rates resulting in reduced GF values (Fig. 9B,C). This result suggests that bFGF partly mediates the mitogenic thalamic effect either by increasing the responsiveness of cortical precursors to another growth factor (Ciccolini and Svendsen, 1998) or by acting directly in cooperation with other factors.

\section{Influence of TCM on cortical precursor differentiation}

The present findings show that under the influence of TCM, a greater proportion of cortical precursors do not differentiate, but rather continue their progression in the cell cycle and exhibit a shorter $\mathrm{G}_{1}$-phase duration. This raises several questions. For instance, are the cortical precursors treated by TCM prevented from differentiation? Does TCM selectively influence the proliferation of glial or neuronal lineages? 
Table 1. Influence of thalamus-conditioned medium (TCM) and fetal calf serum (FCS) on cell-cycle parameters

\begin{tabular}{|c|c|c|c|}
\hline & $\begin{array}{l}\text { Cell density } \\
(\% \text { increase })\end{array}$ & $\begin{array}{l}\text { Growth fraction } \\
\text { (\% increase) }\end{array}$ & $\begin{array}{l}\text { Labelling index } \\
\text { (\% increase) }\end{array}$ \\
\hline \multirow[t]{6}{*}{ TCM in the presence of FCS (TCM + FCS versus GMEM + FCS) six experiments } & $+19 * * *$ & $+17^{* *}$ & $+18 * *$ \\
\hline & $+17 * * *$ & $+11 * *$ & $+28 * *$ \\
\hline & $+36 * * *$ & $+7 * * *$ & $+25^{* *}$ \\
\hline & $+19 * *$ & $+12^{* * *}$ & $+22^{*}$ \\
\hline & $+28 * *$ & $+12^{* * *}$ & $+12^{*}$ \\
\hline & $+22 * * *$ & $+12 * * *$ & $+25^{* * *}$ \\
\hline \multirow[t]{2}{*}{ TCM in the absence of FCS (TCM versus GMEM) two experiments } & $+42 * * *$ & $+11^{*}$ & $+24 * * *$ \\
\hline & $+60 * * *$ & $+26^{* * *}$ & $+26^{* *}$ \\
\hline \multirow[t]{2}{*}{ FCS in the absence of TCM (GMEM + FCS versus GMEM) two experiments } & $+46^{* * *}$ & $+15^{*}$ & $+16 \mathrm{~ns}$ \\
\hline & $+34 * * *$ & $+15^{* *}$ & $+17^{*}$ \\
\hline
\end{tabular}

Statistical analysis of the differences: Mann-Whitney U test $\left({ }^{*} p<0.05,{ }^{* *} p<0.005, * * * p<0.0005\right)$.

E18 cortex in presence of E15 TCM
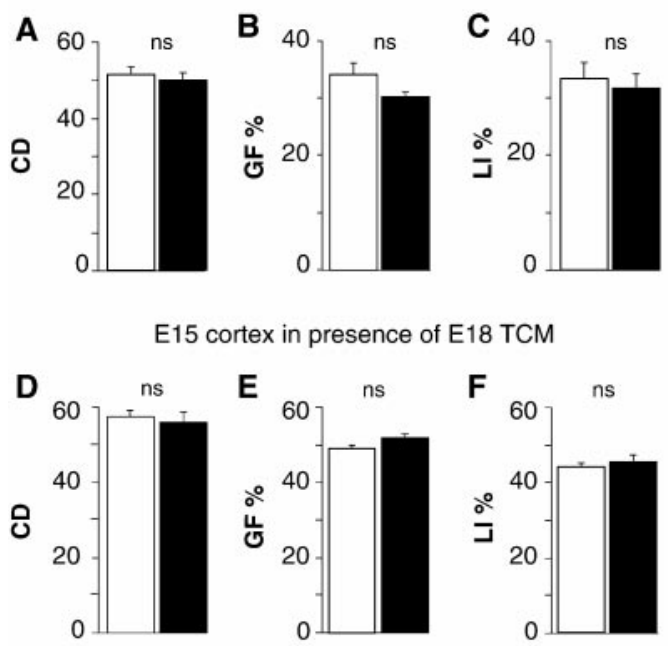

$\square$ GMEM+FCS

$\mathrm{TCM}+\mathrm{FCS}$

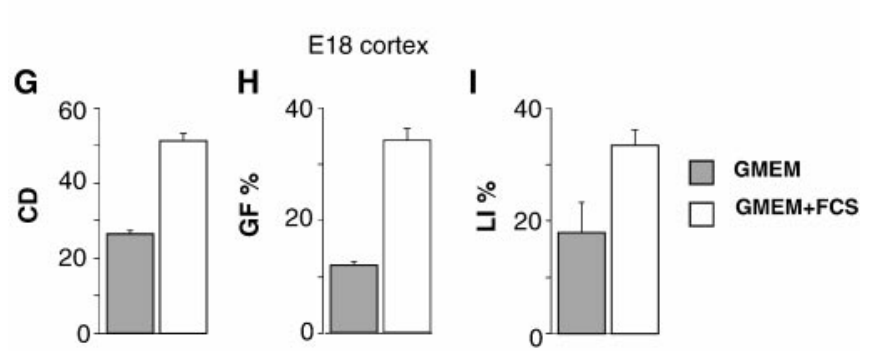

Figure 7. $A-C, \mathrm{CD}, \mathrm{GF}$, and $\mathrm{LI}$ in E18 cortical precursors grown in GMEM $+10 \%$ FCS and in TCM prepared from E15 thalamus (1 of 2 experiments). $D-F, \mathrm{CD}, \mathrm{GF}$, and $\mathrm{LI}$ in E15 cortical precursors grown in GMEM $+10 \%$ FCS and in TCM prepared from E18 thalamus ( 1 of 2 experiments). $G-I, \mathrm{CD}, \mathrm{GF}$, and $\mathrm{LI}$ in E18 cortical precursors grown in GMEM and in GMEM $+10 \%$ FCS, showing that FCS exerts a strong mitogenic effect on the E18 cortical precursors.

To examine whether TCM prevents differentiation, we have investigated the influence of TCM on the proportions of MAP2and GFAP-positive cells in dissociated cultures maintained for 5 DIV. Both GFAP- and MAP2-positive cell numbers are found to increase with time in control cultures (Fig. 10A,B). In TCMtreated cultures, the GFAP-positive cell number increase is bigger than in control cultures (Fig. 10 $A$ ). We found that all GFAPpositive cells are also PCNA positive (see Fig. $1 F$ ). Although the GF substantially increases in TCM-treated cultures, the GFAP/

\section{E14 cortex in presence of E14 TCM}
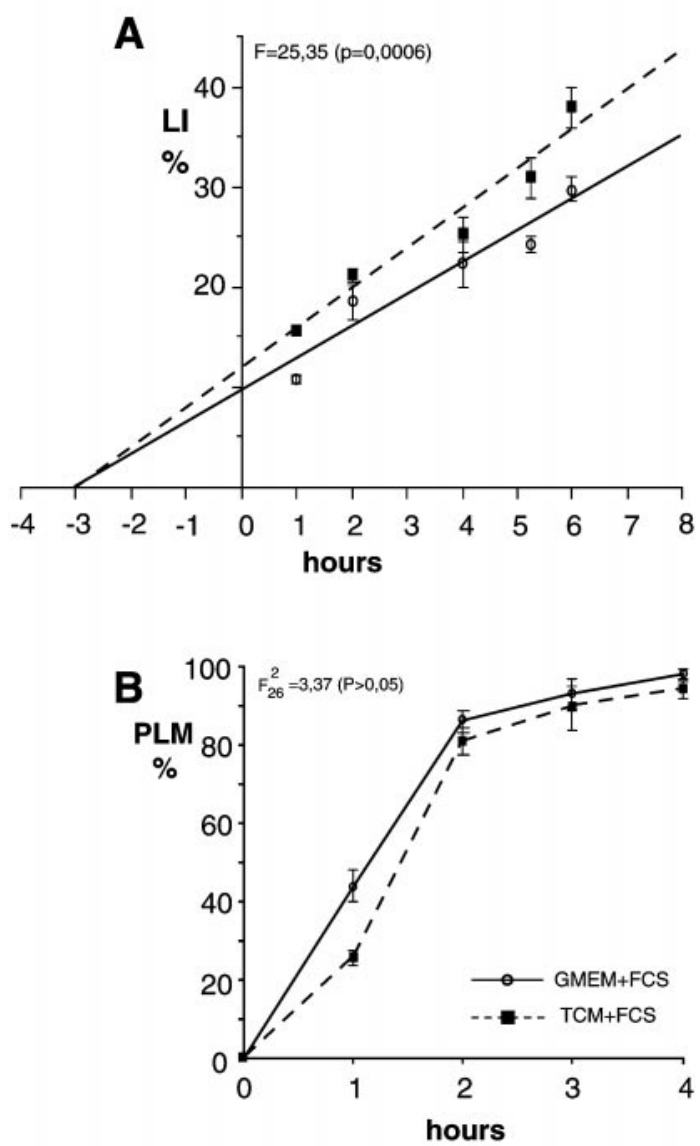

Figure 8. Analysis of cell-cycle kinetics in E14 cultures, showing that TCM reduces cell-cycle duration via the $\mathrm{G}_{1}$ phase. $A$, BrdUrd cumulative labeling indicates the duration of the cell cycle $(\mathrm{Tc} ; 31.5 \mathrm{hr}), \mathrm{S}$ phase $(\mathrm{Ts}$; $3 \mathrm{hr}$ ), and $\mathrm{G}_{1}+\mathrm{G}_{2}+\mathrm{M}$ phases $(28.2 \mathrm{hr})$ in E14 control cultures $(G M E M+F C S)$. TCM + FCS gives a $6 \mathrm{hr}$ reduction of Tc; Ts remains constant. LI values are \pm SEM. F test statistical analysis indicates that the two slopes are different. $B$, Percentage of labeled mitoses (PLM) indicates the duration of the $\mathrm{G}_{2}+\mathrm{M}$ phases. In the presence and absence of TCM, $\mathrm{G}_{2}+\mathrm{M}$ duration was $3.5 \mathrm{hr}$, indicating that TCM regulates the duration of Tc via the $G_{1}$ phase (see Results). Values are \pm SEM. Statistical analysis with an $\mathrm{F}$ test shows that the two slopes are identical.

PCNA ratio remains unchanged compared with control cultures and reaches $13 \%$ at 5 DIV (Fig. 10C). This indicates that the 


\section{E15 cortex in presence of E15 thalamic explant}
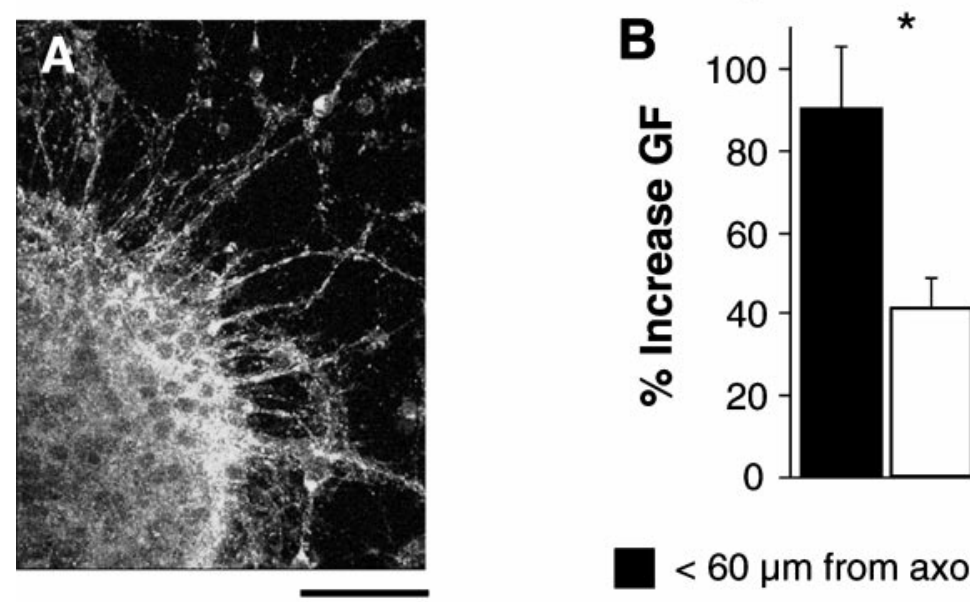

$<60 \mu \mathrm{m}$ from axon terminal

$\square<60 \mu \mathrm{m}$ from axon terminal $+\alpha \mathrm{bFGF}$

\section{E15 cortex in presence of E15 TCM}

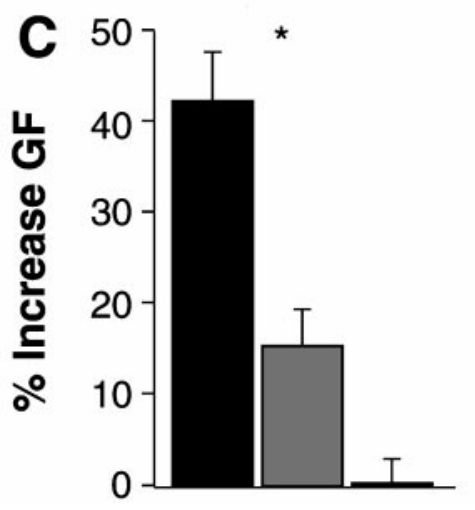

TCM

TCM $+\alpha b F G F$ GMEM+ $\alpha \mathrm{bFGF}$

Figure 9. $A$, Immunostaining of an E15 thalamic explant showing bFGF localization in cell bodies as well as in outgrowing neurites. Scale bar, $50 \mu \mathrm{m}$. $B$, Effect of treatment with an anti-bFGF antibody $(60 \mathrm{ng} / \mathrm{ml})$ on GF in E15 cortical precursors grown in the vicinity of E15 thalamic axons (2 experiments). $C$, Effect of treatment with an anti-bFGF antibody $(60 \mathrm{ng} / \mathrm{ml})$ on GF in E15 cortical precursors grown in GMEM and TCM (2 experiments). The antibody directed against bFGF significantly reduces the increase in GF induced by TCM but does not modify the GF value in the control culture.

fraction of precursors following the glial fate is not altered in 5 DIV TCM-treated cultures and the increase of glial cells in TCM-treated cultures compared with control (Fig. 10A) is directly attributable to the increase in the GF. TCM-treated cultures are characterized by lower MAP2-positive cell numbers (Fig. 10B), in agreement with the fact that TCM treatment results in a higher GF and, conversely, a reduced postmitotic cell proportion compared with normal.

To determine whether more neurons are produced under the influence of TCM, we computed the proportion of MAP2positive cells in a 7 DIV culture; the cells were exposed to TCM for the first 2 DIV and left to survive for an additional 5 DIV. This shows that TCM-exposed cultures are characterized by a higher proportion of MAP2-positive cells (Fig. 10D) and that precursors engage in neuronal differentiation subsequent to the TCM mitogenic effect.

Together, these findings show that the thalamic mitogenic effect (1) influences the proliferation of both glial and neuronal precursors and (2) does not preclude the action of signals that induce differentiation in these two lineages.

\section{Cortical neuroblast proliferation in organotypic culture}

To assess the relevance of the above findings to the in vivo situation, we have sought to determine whether embryonic thalamic axons exert a mitogenic effect in the intact cortex. Proliferation parameters of cortical precursors were examined in organotypic cultures with intact thalamocortical innervation. E15 cortical hemispheres devoid of subcortical innervation and cortical hemispheres attached to the thalamus were cultured for $24 \mathrm{hr}$ and exposed to BrdUrd for $2 \mathrm{hr}$. BrdUrd immunolabeling was then examined on thin sections (Fig. $11 A, B$ ). The results show an increased number of BrdUrd-positive cells in the ventricular zone of the cortex, which was innervated by thalamic afferents, compared with the isolated cortex.

In a second series of experiments, E15 cortical hemispheres devoid of subcortical innervation and cortical hemispheres attached to the thalamus were cultured $8 \mathrm{hr}$ after dissection. BrdUrd was added to the culture medium for $4 \mathrm{hr}$ before microdissection and dissociation of the embryonic telencephalic wall. Dissociated cells were then plated on polylysine-laminin-coated coverslips and fixed $8 \mathrm{hr}$ after plating. Because labeled and unla- 


\section{E15 cortex in presence of E15 TCM}
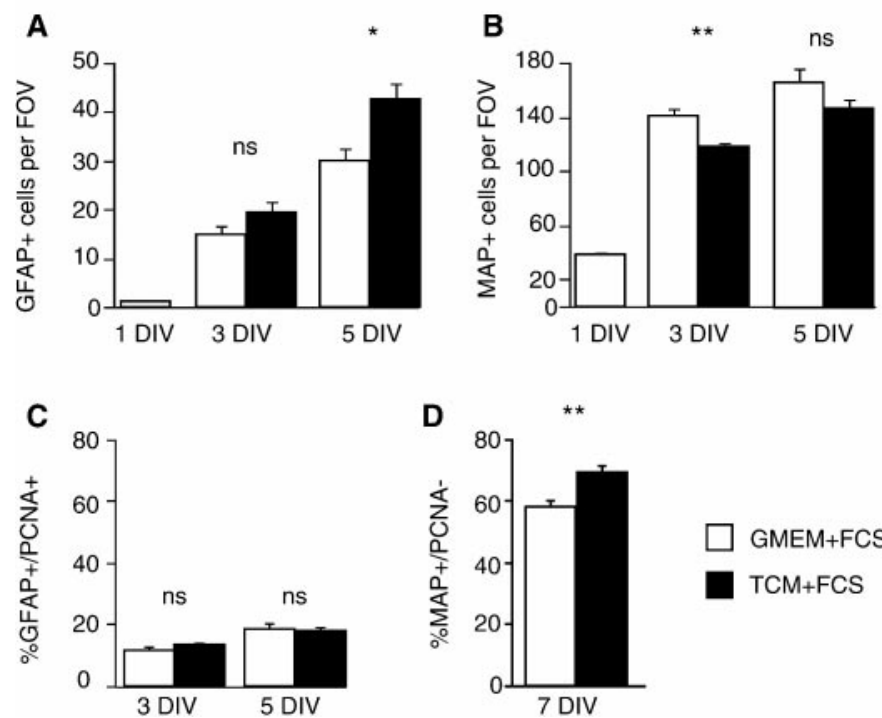

GMEM+FCS

$\mathrm{TCM}+\mathrm{FCS}$

Figure 10. Quantitative analysis of glial and neuronal populations in E15 control cultures $(G M E M+F C S)$ and in TCM + FCS-treated cultures. $A$, Number of GFAP + cells per FOV. $B$, Number of MAP2 + cells per FOV. $C$, Proportions of GFAP + cells with respect to the GF. $D$, Percentage of MAP2 + cells with respect to the postmitotic population in a 7 DIV culture. Values are \pm SEM.

beled precursors will have identical rates of proliferation subsequent to the pulse, the labeling indices can be examined after the time period that is required to allow precursors to attach to the coverslips (Fig. 11C).

The results show that both GF and LI values are significantly increased in the case of the thalamocortical organotypic culture, compared with the isolated hemispheres (Fig. 11C). These experiments performed in organotypic cultures show that in the cytoarchitecturally intact system, thalamic afferents stimulate the proliferation of cortical precursors. Therefore, the mitogenic effect of thalamic axons on dissociated cell cultures is not an artifact of cell dissociation, but instead reflects a developmental role of thalamic innervation in the cytoarchitecturally intact system.

\section{DISCUSSION}

Before discussing the significance of these results for neurogenesis and corticogenesis, we need to address the relevance of the present findings to in vivo development. Thalamic afferents in vivo are in a position to exert a mitogenic effect on cortical precursors. Axonal tracing experiments at E15 show that ingrowing thalamocortical axons lie within $80 \mu \mathrm{m}$ of the ventricular zone (Erzurumlu and Jhaveri, 1992; Polleux et al., 1996). One possibility is that thalamic fibers signal over these distances to the cortical precursors in the germinal zones or via their close contacts with radial glia (Godement et al., 1987; Erzurumlu and Jhaveri, 1992; Kageyama and Robertson, 1993). Furthermore, thalamic axons can directly contact those precursors located in the intermediate zone (Smart, 1973; Shoukimas and Hinds, 1978; Valverde et al., 1995).

We have directly addressed the issue of a mitogenic influence of thalamic afferents in vivo with organotypic cultures. The increased proliferation observed in the hemispheres that are attached to the thalamus cannot be the result of monoaminergic innervation from the brainstem, which is excluded in this preparation, nor of cholinergic innervation from the basal forebrain, which is not formed until later in development (Dinopoulos et al., 1989; Kiss and Patel, 1992).

The specificity of the effect has been addressed by examining its developmental timetable. The mitogenic effect is observed when thalamic fibers enter the lateral wall of the E15 telencephalic vesicle (Bicknese et al., 1994; Polleux et al., 1996). TCM derived from E18 thalamus fails to show a mitogenic effect, and this corresponds to a stage when thalamic axons are growing into the cortical plate (Bicknese et al., 1994). The competence of cortical precursors to respond to the thalamic mitogenic effect is temporally restricted because E18 precursors fail to respond to TCM. Hence, the short period during which a mitogenic effect can be demonstrated is restricted to the developmental time window when cortical afferents are in close proximity to cortical precursors.

\section{Candidate molecule for the mitogenic effect}

Numerous extrinsic factors have been shown to modulate cortical neuroblast proliferation (Cameron et al., 1998). These include widely expressed growth factors [bFGF, EGF, IGF, TGF- $\beta$, and pituitary adenylate cyclase-activating polypeptide (PACAP)], neurotrophic factors (NT3, NT4, BDNF, and NGF), and neurotransmitters (GABA, glutamate, VIP, and monoamines). Factors that have been reported to promote neuroblast proliferation include NGF (Cattaneo and McKay, 1990), bFGF (Ghosh and Greenberg, 1995; Cavanagh et al., 1997), EGF (Burrows et al., 1997), IGF (Nielsen and Gammeltoft, 1990; Ye et al., 1996), and VIP (Gressens et al., 1998), whereas 5-hydroxytryptamine (5HT) (Lavdas et al., 1997), norepinephrine (Ghiani et al., 1999), glutamate and GABA (LoTurco et al., 1995), and PACAP (Lu and DiCicco-Bloom, 1997; DiCicco-Bloom et al., 1998) have been shown to inhibit proliferation and/or to elicit cell-cycle withdrawal.

Although the signaling molecule that is delivered to the embryonic cortex by thalamic axons and acts as a positive regulator of neurogenesis has not been identified, this study suggests that bFGF is involved. The thalamus-derived signal can act directly or via the induction of secondary signals from resident cell populations. bFGF is one putative signal that embryonic thalamic axons could deliver to the embryonic cortex. bFGF immunoreactivity is present in embryonic thalamic neurons (Lotto et al., 1997) and axons (present results), in agreement with the demonstration that bFGF can be anterogradely transported (von Bartheld et al., 1996). Although bFGF is a potent mitogen for cortical precursors (Ghosh and Greenberg, 1995; Vaccarino et al., 1999), it may also exert its effects through the induction of responsiveness to other factors (Ciccolini and Svendsen, 1998).

\section{Mitogenic effect on the dynamics of the cell cycle}

The influence of the thalamus-derived factor exclusively on the duration of the $G_{1}$ phase of the cell cycle is in agreement with a number of studies showing that, in most eukaryotic cell types, cell-cycle duration is regulated mainly via $\mathrm{G}_{1}$ (Pardee, 1989) and that $\mathrm{Ts}$ and $\mathrm{G}_{2} / \mathrm{M}$-phase duration are highly conserved during neurogenesis (Kaufmann, 1968; Waechter and Jaensch, 1972; Schultze et al., 1974; Schmahl, 1983; Reznikov and van der Kooy, 1995; Miyama et al., 1997).

The fact that TCM influences the commitment of cortical precursors through cell-cycle progression suggests that it contains factors that inhibit growth arrest by promoting $G_{1} / S$ transition in 

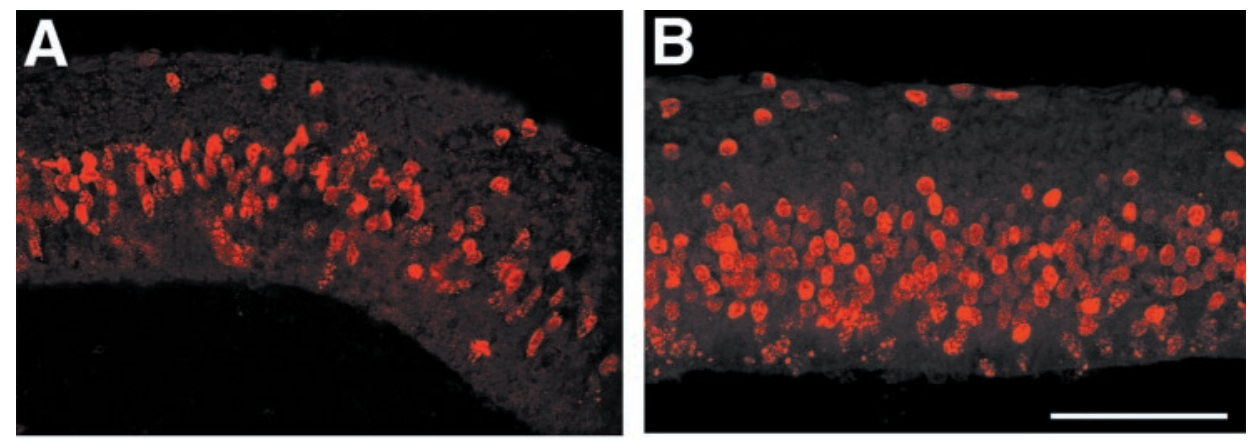

\section{C}

\section{E15 organotypic thalamocortical culture}
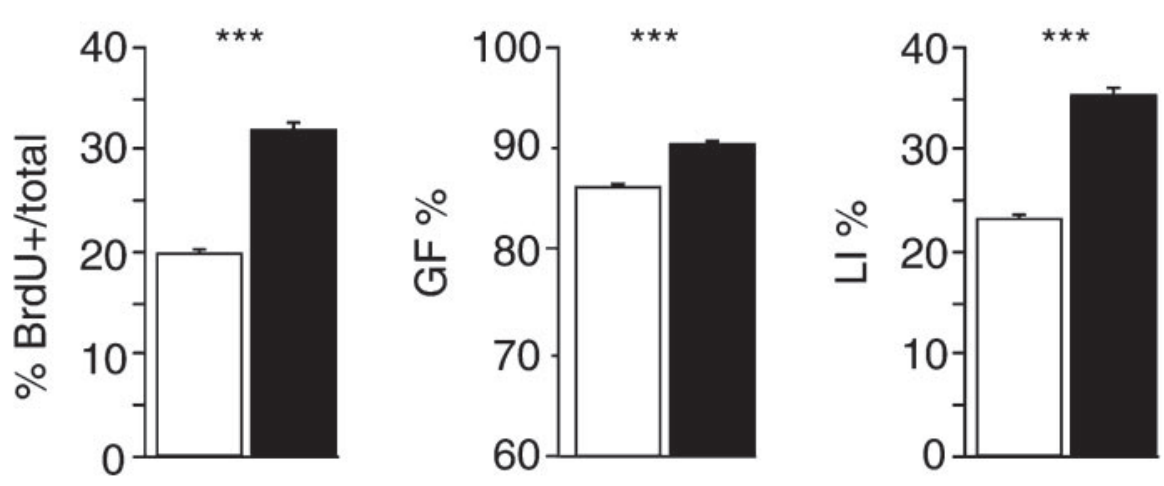

\section{isolated cortex}

thalamus + cortex
Figure 11. Proliferation parameters in E15 organotypic cultures. $A$, BrdUrd+ cells in a section of an organotypic culture of cortex innervated by thalamus. $B$, BrdUrd + cells in a section of an organotypic culture of isolated cortex. $C$, Growth fraction $(G F)$ and labeling index $(L I)$ are increased in organotypic thalamocortical coculture compared with isolated cortex culture. cortical precursors. Accordingly, the thalamus-derived factors may upregulate the expression of positive cell-cycle regulators such as D cyclins or downregulate the expression of cell-cycle inhibitors such as cyclin-dependent kinase inhibitors (Sherr and Roberts, 1999). Consistent with a major role in positive regulation of $\mathrm{G}_{1}$ progression, the $\mathrm{D}$-type cyclins are required for $S$-phase entry, and their overexpression accelerates $G_{1}$ and reduces dependency on exogenous growth factors (Baldin et al., 1993; Quelle et al., 1993; Lukas et al., 1994).

The present results concerning the effect of the thalamusderived mitogenic factor on $\mathrm{G}_{1} / \mathrm{S}$ transition agree with observations in invertebrates. Work in the Drosophila shows that innervation from the optic nerve facilitates the $G_{1} / S$ transition of central precursors (Selleck et al., 1992; Huang and Kunes, 1998).

In the mouse telencephalon, thalamus afferents exert a mitogenic influence in midcorticogenesis. Because of the spatial proximity of the thalamic axons to the ventricular and subventricular zones, the mitogenic effect would be expected to differentially affect subventricular and ventricular precursors (Haydar et al., 2000). Cell-cycle progression is controlled by multiple (intrinsic and extrinsic) inhibitory and excitatory regulators (see above). The present result suggests that thalamic afferents exert a control over corticogenesis by modulating rates of proliferation and thereby offsetting the lengthening of the cell cycle in late corticogenesis (Schmahl 1983; Takahashi et al., 1995). Such a control mechanism could serve to adjust final cortical cell numbers with respect to the sensory periphery (Kennedy and Dehay, 1997).

\section{Afferent control of morphogenesis in the CNS}

A number of studies in invertebrates suggest that peripheral axons regulate morphogenesis of target structures. Work on leech genitalia shows that peripheral organs can regulate central neurogenesis (Baptista et al., 1990). In the visual system of the crustacea Daphnia magna, lesions of growing optic axons reduce the numbers of target neurons (Macagno, 1979). In Drosophila, optic axons promote the proliferation of target precursor neurons (Selleck et al., 1992). In vertebrate CNS development, only a few reports have examined the role of afferent axons in the regulation of CNS proliferation. Eye removal during early frog development results in lower mitotic rates in the regions of the tectum that are innervated by the optic axons (Kollros, 1953, 1982). In the olfactory system, afferent axons influence the proliferation and differentiation of target progenitors in the telencephalon (Gong and Shipley, 1995).

A number of studies in rodent and primate provide indirect evidence in favor of an afferent control of corticogenesis. Regionalization of cell-cycle kinetics in the ventricular zone plays a determinant role in the generation of cytoarchitecturally distinct neocortical areas characterized by different numbers of neurons per unit area of cortical surface (Dehay et al., 1993; Polleux et al., 1997), and increased rates of proliferation are characteristic of precursors of areas containing high numbers of neurons (Dehay et al., 1993; Polleux et al., 1997, 1998). Note that the increase in proliferation rates that are characteristic of A17 precursors in the 
primate visual cortex is observed at a stage when thalamic axons are in close proximity to the germinal zones (Dehay et al., 1993). Significantly, depletion of geniculocortical axons leads to a drastic reduction of neuron number and of surface area of the target area (Rakic, 1988; Dehay et al., 1989, 1996).

Thalamic influence on cortical proliferation is likely to be one of many extracellular factors regulating cortical neurogenesis. A number of potential sources of neurotransmitters can influence precursor proliferation in the ventricular zone (LaMantia, 1995). Monoaminergic afferents originating from the brainstem and midbrain (Moore et al., 1978) are among the first axons to innervate the embryonic telencephalic wall shortly after the onset of neuron production (Wallace and Lauder, 1983) and are likely to influence cortical proliferation because monoaminergic receptors are expressed by neuroepithelial cells of the ventricular zone (Johnson and Heinemann, 1995). A recent study (Lavdas et al., 1997) has provided evidence that 5-HT promotes the differentiation of glutamatergic neurons, without affecting precursor proliferation. Precursors of the cortical ventricular zone express adrenergic receptors (Lidow and Rakic, 1995; Wang and Lidow, 1997), and norepinephrine triggers cell-cycle arrest in oligodendrocytes (Ghiani et al., 1999). GABAergic cells and processes (as well as other neurotransmitter-containing processes) are located in close proximity to the germinal zones (Lauder et al., 1986; Parnavelas and Cavanagh, 1988). Glutamate and GABA influence DNA synthesis of cortical precursors in the rat ventricular and subventricular zones (LoTurco et al., 1995, Haydar et al., 2000). There is evidence suggesting that the cortical plate exerts an inhibitory feedback influence on proliferation in the ventricular zone (DiCicco-Bloom et al., 1998; Polleux et al., 1998) that could be relayed by descending corticofugal axons (Kim et al., 1991; Miller et al., 1993; McConnell et al., 1994; Meyer et al., 1998).

The present results could appear at odds with the recent findings reported by Miyashita-Lin et al. (1999) on Gbx2 mutants and by Nakagawa et al. (1999) on Mash mutants characterized by an impairment of thalamocortical projections throughout development and in which neocortical region-specific gene expression is reported to develop normally. Although these studies convincingly show that regionalized gene expression in the mutants followed a normal developmental process, they did not address their areal cytoarchitecture and regionalized differences in neuron number, which would require stereological examination of the newborn cortex (Skoglund et al., 1996). More recently, Bishop et al. (2000) and Mallamaci et al. (2000) provided further evidence for a genetic determination of areal identity in the neocortex. Together, these findings underlie the notion that specification of cortical area identity results from an interplay between intrinsic and extrinsic factors.

\section{Conclusion}

The differential distribution of thalamocortical projections, acting in combination with other neurotransmitter-containing afferent systems, could provide a tight spatiotemporal regulation of proliferation rates in the ventricular zone. Precursors of the six layers of the neocortex exit the cell cycle according to a precisely defined spatiotemporal pattern (Angevine and Sidman, 1961; Smart and Smart, 1982; Bayer and Altman, 1991; Takahashi et al., 1999). The modulation of cell-cycle withdrawal will have farreaching consequences because the environmental signals encountered during the final round of mitosis play a major role in determining neuronal fate (McConnell and Kaznowski, 1991;
Gotz and Bolz, 1994; Bohner et al., 1997; Eagleson et al., 1997). Therefore, the interplay between positive and negative regulators of cortical proliferation, by regulating the timing of cell-cycle exit, will contribute to the control of neuron number, cell fate, and ultimately areal and laminar specification.

\section{REFERENCES}

Alexiades MR, Cepko C (1996) Quantitative analysis of proliferation and cell cycle length during development of the rat retina. Dev Dyn 205:293-307.

Angevine JB, Sidman RL (1961) Autoradiographic study of cell migration during histogenesis of cerebral cortex in the mouse. Nature 192:766-768.

Arimatsu Y, Miyamoto M, Nihonmatsu I, Hirata K, Uratani Y, Hatanaka Y, Takiguchi-Hayashi K (1992) Early regional specification for a molecular neuronal phenotype in the rat neocortex. Proc Natl Acad Sci USA 89:8879-8883.

Baldin V, Lukas J, Marcote MJ, Pagano M, Draetta G (1993) Cyclin D1 is a nuclear protein required for cell cycle progression in G1. Genes Dev 5:812-821.

Baptista CA, Gershon TR, Macagno ER (1990) Peripheral organs control central neurogenesis in the leech. Nature 346:855-858.

Bayer SA, Altman J (1991) Neocortical development. New York: Raven.

Bicknese AR, Sheppard AM, O'Leary DDM, Pearlman AL (1994) Thalamocortical axons extend along a chondroitin sulfate proteoglycan-enriched pathway coincident with the neocortical subplate and distinct from the efferent path. J Neurosci 14:3500-3510.

Bishop KM, Goudreau G, O'Leary DDM (2000) Regulation of area identity in the mammalian neocortex by Emx2 and Pax6. Science 288:344-348

Blaschke AJ, Weiner JA, Chun J (1998) Programmed cell death is a universal feature of embryonic and postnatal neuroproliferative regions throughout the central nervous system. J Comp Neurol 396:39-50.

Bohner AP, Akers RM, McConnell SK (1997) Induction of deep layer cortical neurons in vitro. Development 124:915-923.

Bolton WE, Freeman JW, Mikulka WR, Healy CG, Schmittling RJ, Kenyon NS (1994) Expression of proliferation-associated antigens (PCNA, p120, p145) during the reentry of $\mathrm{G}_{0}$ cells into the cell cycle. Cytometry 17:66-74.

Bravo R, Fey SJ, Bellatin J, Larsen PM, Arevalo J, Celis JE (1981) Identification of a nuclear and of a cytoplasmic polypeptide whose relative proportions are sensitive to changes in the rate of cell proliferation. Exp Cell Res 136:311-319.

Burrows RC, Wancio D, Levitt P, Lillien L (1997) Response diversity and the timing of progenitor cell maturation are regulated by developmental changes in EGFR expression in the cortex. Neuron 19:251-267.

Cameron HA, Hazel TG, McKay RD (1998) Regulation of neurogenesis by growth factors and neurotransmitters. J Neurobiol 36:287-306.

Cattaneo E, McKay R (1990) Proliferation and differentiation of neuronal stem cells regulated by nerve growth factor. Nature 347:762-765.

Cavanagh JF, Mione MC, Pappas IS, Parnavelas JG (1997) Basic fibroblast growth factor prolongs the proliferation of rat cortical progenitor cells in vitro without altering their cell cycle parameters. Cereb Cortex 7:293-302.

Ciccolini F, Svendsen CN (1998) Fibroblast growth factor 2 (FGF-2) promotes acquisition of epidermal growth factor (EGF) responsiveness in mouse striatal precursor cells: identification of neural precursors responding to both EGF and FGF-2. J Neurosci 18:7869-7880.

Cohen-Tannoudji M, Babinet C, Wassef M (1994) Early determination of a mouse somatosensory cortex marker. Nature 368:460-463.

Darmon M, Bottenstein J, Sato G (1981) Neural differentiation following culture of embryonal carcinoma cells in a serum-free defined medium. Dev Biol 85:463-473.

Dehay C, Horsburgh G, Berland M, Killackey HP, Kennedy H (1989) Maturation and connectivity of the visual cortex in monkey is altered by prenatal removal of retinal input. Nature 337:265-267.

Dehay C, Giroud P, Berland M, Smart I, Kennedy H (1993) Modulation of the cell cycle contributes to the parcellation of the primate visual cortex. Nature 366:464-466.

Dehay C, Giroud P, Berland M, Killackey HP, Kennedy H (1996) The contribution of thalamic input to the specification of cytoarchitectonic cortical fields in the primate: effects of bilateral enucleation in the fetal monkey on the boundaries and dimensions of striate and extrastriate cortex. J Comp Neurol 367:70-89.

DiCicco-Bloom E, Lu N, Pintar JE, Zhang J (1998) The PACAP ligand/ receptor system regulates cerebral cortical neurogenesis. Ann NY Acad Sci 865:274-289.

Dinopoulos A, Eadie LA, Dori I, Parnavelas JG (1989) The development of basal forebrain projections to the rat visual cortex. Exp Brain Res 76:563-571.

Eagleson KL, Lillien L, Chan AV, Levitt P (1997) Mechanisms specifying area fate in cortex include cell-cycle-dependent decisions and the 
capacity of progenitors to express phenotype memory. Development 124:1623-1630.

Erzurumlu RS, Jhaveri S (1992) Emergence of connectivity in the embryonic rat parietal cortex. Cereb Cortex 2:336-352.

Ghiani CA, Eisen AM, Yuan X, DePinho RA, McBain CJ, Gallo V (1999) Neurotransmitter receptor activation triggers p27(Kip1) and p21(CIP1) accumulation and G1 cell cycle arrest in oligodendrocyte progenitors. Development 126:1077-1090.

Ghosh A, Greenberg ME (1995) Distinct roles for bFGF and NT-3 in the regulation of cortical neurogenesis. Neuron 15:89-103.

Godement P, Salaün J, Metin C (1987) Fate of uncrossed retinal projections following early or late prenatal monocular enucleation in the mouse. J Comp Neurol 255:97-109.

Gong QH, Shipley MT (1995) Evidence that pioneer olfactory axons regulate telencephalon cell cycle kinetics to induce the formation of the olfactory bulb. Neuron 14:91-101.

Gotz M, Bolz J (1994) Differentiation of transmitter phenotypes in rat cerebral cortex. Eur J Neurosci 6:18-32.

Gressens P, Paindaveine B, Hill JM, Evrard P, Brenneman DE (1998) Vasoactive intestinal peptide shortens both $\mathrm{G} 1$ and $\mathrm{S}$ phases of neural cell cycle in whole postimplantation cultured mouse embryos. Eur J Neurosci 10:1734-1742.

Guibert A, Dehay C, Savatier P, Cortay V, Kennedy H (1995) In vitro proliferation of mouse cortical precursors. Soc Neurosci Abstr 21:44.

Haydar TF, Kuan CY, Flavell RA, Rakic P (1999a) The role of cell death in regulating the size and shape of the mammalian forebrain. Cereb Cortex 9:621-626.

Haydar TF, Bambrick LL, Krueger BK, Rakic P (1999b) Organotypic slice cultures for analysis of proliferation, cell death, and migration in the embryonic neocortex. Brain Res Brain Res Protoc 4:425-437.

Haydar TF, Wang F, Schwartz ML, Rakic P (2000) Differential modulation of proliferation in the neocortical ventricular and subventricular zones. J Neurosci 20:5764-5774.

Huang Z, Kunes S (1998) Signals transmitted along retinal axons in Drosophila: hedgehog signal reception and the cell circuitry of lamina cartridge assembly. Development 125:3753-3764.

Johnson DS, Heinemann SF (1995) Embryonic expression of the 5-HT3 receptor subunit 5-HT3R-A, in the rat: an in situ hybridization study. Mol Cell Neurosci 6:122-138.

Kageyama GH, Robertson RT (1993) Development of geniculocortical projections to visual cortex in rat: evidence for early ingrowth and synaptogenesis. J Comp Neurol 335:123-148.

Kaufmann SL (1968) Lengthening of the generation cycle during embryonic differentiation of the mouse neural tube. Exp Cell Res 49:420424.

Kennedy H, Dehay C (1997) The nature and nurture of cortical development. In: Normal and abnormal development of cortex (Galabulda AM, Christen Y, eds), pp 25-56. Berlin-Heidelberg, New York: Springer.

Killackey HP (1990) Neocortical expansion: an attempt towards relating phylogeny and ontogeny. J Cognit Neurosci 2:1-17.

Kilpatrick TJ, Talman PS, Bartlett PF (1993) The differentiation and survival of murine neurons in vitro is promoted by soluble factors produced by an astrocytic cell line. J Neurosci Res 35:147-161.

Kim GJ, Shatz CJ, McConnell SK (1991) Morphology of pioneer and follower growth cones in the developing cerebral cortex. J Neurobiol 22:629-642.

Kiss J, Patel AJ (1992) Development of the cholinergic fibers innervating the cerebral cortex of the rat. Int J Dev Neurosci 10:153-170.

Kollros JJ (1953) The development of the optic lobes in the frog. I. The effects of unilateral enucleation in embryonic stages. J Exp Zool 123:153-187.

Kollros JJ (1982) Peripheral control of midbrain mitotic activity in the frog. J Comp Neurol 205:171-178.

LaMantia AS (1995) The usual suspects: GABA and glutamate may regulate proliferation in the neocortex. Neuron 15:1223-1225.

Lauder JM, Han VKM, Henderson P, Verdoorn T, Towle AC (1986) Prenatal ontogeny of the GABAergic system in the rat brain: an immunocytochemical study. Neuroscience 19:465-493.

Lavdas AA, Blue ME, Lincoln J, Parnavelas JG (1997) Serotonin promotes the differentiation of glutamate neurons in organotypic slice cultures of the developing cerebral cortex. J Neurosci 17:7872-7880.

Levitt P, Barbe MF, Eagleson KL (1997) Patterning and specification of the cerebral cortex. Annu Rev Neurosci 20:1-24.

Lidow MS, Rakic P (1995) Neurotransmitter receptors in the proliferative zones of the developing primate occipital lobe. J Comp Neurol 360:393-402.

Lotto RB, Price DJ (1996) Effects of subcortical structures on the growth of cortical neurites in vitro. NeuroReport 7:1185-1188.

Lotto RB, Clausen JA, Price DJ (1997) A role for neurotrophins in the survival of murine embryonic thalamic neurons. Eur J Neurosci 9:1940-1949.

LoTurco JJ, Owens DF, Heath MJ, Davis MB, Kriegstein AR (1995) GABA and glutamate depolarize cortical progenitor cells and inhibit DNA synthesis. Neuron 15:1287-1298.
Lu N, DiCicco-Bloom E (1997) Pituitary adenylate cyclase-activating polypeptide is an autocrine inhibitor of mitosis in cultured cortical precursor cells. Proc Natl Acad Sci USA 94:3357-3362.

Lukas J, Pagano M, Staskova Z, Draetta G, Bartek J (1994) Cyclin D1 protein oscillates and is essential for cell cycle progression in human tumour cell lines. Oncogene 9:707-718.

Macagno ER (1979) Cellular interactions and pattern formation in the development of the visual system of Daphnia magna (Crustacea, Branchiopoda). Dev Biol 73:206-238.

Mallamaci A, Muzio L, Chan CH, Parnavelas J, Boncinelli E (2000) Area identity shifts in the early cerebral cortex of Emx2 -/- mutant mice. Nat Neurosci 3:679-686.

McConnell SK (1995) Strategies for the generation of neuronal diversity in the developing central nervous system. J Neurosci 15:6987-6998.

McConnell SK, Kaznowski CE (1991) Cell cycle dependence of laminar determination in developing neocortex. Science 254:282-285.

McConnell SK, Ghosh A, Shatz CJ (1994) Subplate pioneers and the formation of descending connections from cerebral cortex. J Neurosci 14:1892-1907.

Meyer G, Soria JM, Martinez-Gala JR, Martin-Clemente B, Fairen A (1998) Origins and developmental histories of transient neurons in the marginal zone of the fetal and neonatal rat cortex. J Comp Neurol 397:493-518.

Miller B, Chou L, Finlay BL (1993) The early development of thalamocortical and corticothalamic projections. J Comp Neurol 335:16-41.

Miller MW, Nowakowski RS (1991) Effects of prenatal exposure to ethanol on the cell cycle kinetics and growth fraction in the proliferative zones of fetal rat cerebral cortex. Alcohol Clin Exp Res 15:229-232.

Miyama S, Takahashi T, Nowakowski RS, Caviness Jr VS (1997) A gradient in the duration of the G1 phase in the murine neocortical proliferative epithelium. Cereb Cortex 7:678-689.

Miyashita-Lin EM, Hevner R, Wassarman KM, Martinez S, Rubenstein JL, Wang F, Lidow MS (1999) Early neocortical regionalization in the absence of thalamic innervation. Science 285:906-909.

Moore RY, Halaris AE, Jones BE (1978) Serotonin neurons of the midbrain raphe: ascending projections. J Comp Neurol 180:417-438.

Nakagawa Y, Johnson JE, O'Leary DD (1999) Graded and areal expression patterns of regulatory genes and cadherins in embryonic neocortex independent of thalamocortical input. J Neurosci 24:10877-10885.

Nielsen FC, Gammeltoft S (1990) Mannose-6-phosphate stimulates proliferation of neuronal precursor cells. FEBS Lett 262:142-144.

Nowakowski RS, Lewin SB, Miller MW (1989) Bromodeoxyuridine immunohistochemical determination of the lengths of the cell cycle and the DNA-synthetic phase for an anatomically defined population. J Neurocytol 18:311-318.

O'Leary DDM (1989) Do cortical areas emerge from a protocortex? Trends Neurosci 12:400-406.

Pardee AB (1989) G1 events and regulation of cell proliferation. Science 246:603-608

Parnavelas JG, Cavanagh ME (1988) Transient expression of neurotransmitters in the developing neocortex. Trends Neurosci 11:92-93.

Polleux F, Dehay C, Kennedy H (1996) Gradients and timing of the arrival of thalamic axons in the mouse neocortex. Soc Neurosci Abstr 22:1012.

Polleux F, Dehay C, Moraillon B, Kennedy H (1997) Regulation of neuroblast cell-cycle kinetics plays a crucial role in the generation of unique features of neocortical areas. J Neurosci 17:7763-7783.

Polleux F, Dehay C, Kennedy H (1998) Neurogenesis and commitment of corticospinal neurons in reeler. J Neurosci 18:9910-9923.

Price DJ, Lotto RB (1996) Influence of the thalamus on the survival of subplate and cortical plate cells in cultured embryonic mouse brain. J Neurosci 16:3247-3255.

Quastler H, Sherman FG (1959) Cell population kinetics in the intestinal epithelium of the mouse. Exp Cell Res 17:420.

Quelle DE, Ashmun RA, Shurtleff SA, Kato JY, Bar-Sagi D, Roussel MF, Sherr CJ (1993) Overexpression of mouse D-type cyclins accelerates G1 phase in rodent fibroblasts. Genes Dev 7:1559-1571.

Rakic P (1988) Specification of cerebral cortical areas. Science 241:170-176.

Repka A, Cunningham TJ (1987) Specific neurotrophic interactions between cortical and subcortical visual structures in developing rat: in vitro studies. J Comp Neurol 256:552-560.

Reznikov K, van der Kooy D (1995) Variability and partial synchrony of the cell cycle in the germinal zone of the early embryonic cerebral cortex. J Comp Neurol 360:536-554.

Sasaki K, Kurose A, Ishida Y (1993) Flow cytometric analysis of the expression of PCNA during the cell cycle in HeLa cells and effects of the inhibition of DNA synthesis on it. Cytometry 14:876-882.

Schmahl W (1983) Developmental gradient of cell cycle in the telencephalic roof of the fetal NMRI-mouse. Anat Embryol 167:355-364.

Schultze B, Nowak B, Maurer W (1974) Cycle times of the neural epithelial cells of various types of neuron in the rat: an autoradiographic study. J Comp Neurol 158:207-218. 
Selleck SB, Steller H (1991) The influence of retinal innervation on neurogenesis in the first optic ganglion of Drosophila. Neuron 6:83-99.

Selleck SB, Gonzalez C, Glover DM, White K (1992) Regulation of the G1-S transition in postembryonic neuronal precursors by axon ingrowth. Nature 355:253-255.

Sherr CJ, Roberts JM (1999) CDK inhibitors: positive and negative regulators of G1-phase progression. Genes Dev 13:1501-1512.

Shoukimas GM, Hinds JW (1978) The development of cerebral cortex in the embryonic mouse: an electron microscopic serial sections analysis. J Comp Neurol 179:795-830.

Skoglund TS, Pasher R, Berthold CH (1996) Heterogeneity in the columnar number of neurons in different neocortical areas in the rat. Neurosci Lett 208:97-100.

Smart IHM (1973) Proliferative characteristics of the ependymal layer during the early development of the mouse neocortex: a pilot study based on recording the number, location and plane of cleavage of mitotic figures. J Anat 116:67-91.

Smart IHM, Smart M (1982) Growth patterns in the lateral wall of the mouse telencephalon: I. Autoradiographic studies of the histogenesis of the isocortex and adjacent areas. J Anat 134:273-298.

Smith AG, Heath JK, Donaldson DD, Wong GG, Moreau J, Stahl M, Rogers D (1988) Inhibition of pluripotential embryonic stem cell differentiation by purified polypeptides. Nature 336:688-690.

Soriano E, Dumesnil N, Auladell C, Cohen-Tannoudji M, Sotelo C (1995) Molecular heterogeneity of progenitors and radial migration in the developing cerebral cortex revealed by transgene expression. Proc Natl Acad Sci USA 92:11676-11680.

Takahashi T, Nowakowski RS, Caviness VS (1993) Cell cycle parameters and patterns of nuclear movement in the neocortical proliferative zone of the fetal mouse. J Neurosci 13:820-833.

Takahashi T, Nowakowski RS, Caviness Jr VS (1995) The cell cycle of the pseudostratified ventricular epithelium of the embryonic murine cerebral wall. J Neurosci 15:6046-6057.

Takahashi T, Goto TT, Miyama S, Nowakowski RS, Caviness VS (1999) Sequence of neuron origin and neocortical laminar fate: relation to cell cycle of origin in the developing murine cerebral wall. J Neurosci 19:10357-10371.

Teague K, el-Naggar A (1994) Comparative flow cytometric analysis of proliferating cell nuclear antigen (PCNA) antibodies in human solid neoplasms. Cytometry 15:21-27.

Temple S, Davis AA (1994) Isolated rat cortical progenitor cells are maintained in division in vitro by membrane-associated factors. Development 120:999-1008.

Vaccarino FM, Schwartz ML, Raballo R, Nilsen J, Rhee J, Zhou M, Doetschman T, Coffin JD, Wyland JJ, Hung YT (1999) Changes in cerebral cortex size are governed by fibroblast growth factor during embryogenesis. Nat Neurosci 2:246-253.

Valverde F, Lopez-Mascaraque L, Santacana M, De Carlos JA (1995) Persistence of early-generated neurons in the rodent subplate: assessment of cell death in neocortex during the early postnatal period. J Neurosci 15:5014-5024.

von Bartheld CS, Byers MR, Williams R, Bothwell M (1996) Anterograde transport of neurotrophins and axodendritic transfer in the developing visual system. Nature 379:830-833.

Waechter RV, Jaensch B (1972) Generation time of the matrix cells during embryonic brain development: an autoradiographic study in rats. Brain Res 46:235-250.

Wallace JA, Lauder JM (1983) Development of the serotonergic system in the rat embryo: an immunocytochemical study. Brain Res Bull 10:459-479.

Wang F, Lidow MS (1997) Alpha 2A-adrenergic receptors are expressed by diverse cell types in the fetal primate cerebral wall. J Comp Neurol 378:493-507.

Williams RW, Herrup K (1988) The control of neuron number. Annu Rev Neurosci 11:423-453.

Windrem MS, Finlay BL (1991) Thalamic ablations and neocortical development: alterations of cortical cytoarchitecture and cell number. Cereb Cortex 3:230-240.

Ye P, Xing Y, Dai Z, D'Ercole AJ (1996) In vivo actions of insulin-like growth factor-I (IGF-I) on cerebellum development in transgenic mice: evidence that IGF-I increases proliferation of granule cell progenitors. Brain Res Dev Brain Res 95:44-54.

Zhou C, Qiu Y, Pereira FA, Crair MC, Tsai SY, Tsai MJ (1999) The nuclear orphan receptor COUP-TFI is required for differentiation of subplate neurons and guidance of thalamocortical axons. Neuron 4:847-859. 